\title{
URBAN LOGISTICS AND SPATIAL TERRITORIAL INTELLIGENCE INDICATORS: STATE OF THE ART, TYPOLOGY AND IMPLICATIONS FOR LATIN AMERICAN CITIES
}

Jesús González-Feliu

École des Mines de Saint-Étienne. Saint-Étienne, France jesus.gonzalez-feliu@emse.fr

\section{Abstract}

This paper reviews the state of the art in spatial accessibility and attractiveness indicators for urban freight transport and logistics, from a territorial intelligence and analytics viewpoint. It proposes a first typology of indicators and analyzes their potential in Latin American urban planning and development. After presenting the main notions of business intelligence and analytics, as well as a definition of territorial intelligence and analytics, the paper proposes an overview of territorial intelligence indicators, focusing on accessibility and attractiveness indicators, and a typology of five categories of indicators: infrastructure-based indicators, generation-based indexes, distance/ time/cost measures, gravity-based indicators and space-time compatibility indexes. Finally, the main issues for implementing such indicators are presented, in terms of data requirements and potential applications focusing on the Latin American context.

Keywords: urban logistics, territorial intelligence and analytics, spatial indicators, accessibility, attractiveness, data production

\section{Resumen}

\section{Logística urbana e indicadores espaciales de inteligencia territorial: Estado del arte, tipología e implicaciones para ciudades de América Latina}

El presente artículo presenta el estado del arte sobre indicadores de accesibilidad y de atractividad espacial para el transporte de carga y la logística urbana, desde el punto de vista de la inteligencia y la analítica territorial. El artículo propone una primera tipología de indicadores, y analiza el potencial de su uso en la planeación y desarrollo urbano en Latinoamérica. Tras presentar las principales nociones de inteligencia y analítica de negocios, y proponer una definición de la inteligencia y analítica territorial, el artículo propone una visión de conjunto de los indicadores de inteligencia territorial, con un foco en los de accesibilidad y atractividad, y una tipología con cinco categorías de indicadores: de infraestructura, de generación, de distancia/tiempo/costo, gravitatorios y de compatibilidad espacio-temporal. Finalmente, se presentan las principales cuestiones en la implementación de dichos indicadores, en términos de requerimientos en datos y de potenciales aplicaciones, con un foco en el contexto latinoamericano.

Palabras clave: logística urbana; inteligencia y analítica territorial; indicadores espaciales; accesibilidad; atractividad; producción de datos 


\section{Introduction}

Urban logistics is nowadays a central subject in both research and practice that involves different stakeholders and mobilizes various disciplines (Taniguchi and Thompson, 2015; Gonzalez-Feliu, 2018). In the last years, the subject has been of particular interest for Latin American cities (HolguinVeras et al., 2018; Rojas Huérfano et al., 2018), not only as "learners" or "deployers" of solutions and actions already tested and validated in other countries (Barbero, 2010; Betanzo-Quezada and Romero, 2010) but also as promoters of innovation and R\&D in the field (Blanco, 2014; GonzalezFeliu, 2018). Indeed, although urban logistics in Latin America has traditionally been seen as a question of implementing and adapting already mature solutions (Dablanc, 2011), with few experiences and deployment actions in the region (Bozzo et al., 2014), the trend is changing and Latin American countries are currently proposing innovations in city logistics, both at the research (De la Barra et al., 2012; Merchán, 2015; Montoya-Torres et al., 2016; Parra Herrera, 2017; ChicaizaVaca and Hidalgo-Carvajal, 2018) and practice level (Fontes Lima Junior et al., 2010; Lama More, 2010; Macário et al., 2011; Blanco et al., 2014; Fransoo et al., 2017).

Also in the industrial and distribution logistics fields, the application of decisionsupport tools is starting to be standardized and generalized at the Latin American level in various services and directions of companies (Padilla, 2006). Moreover, the notion of business intelligence and analytics is nowadays known in Latin American large and mediumsized companies (Sánchez Veas, 2004; Muller, 2007; Gonzales et al., 2015), although it is not systematically implemented and deployed (Coba et al., 2018).

On another hand, Latin American cities are known for having strong difficulties in terms of urban planning (Cabeza, 2002; Metzger et al., 2015; Alexandri et al., 2016). The inclusion of urban freight in urban plans and actions, which is imperative or at least strongly recommended in many countries of Europe and in the US (Gonzalez-Feliu, 2018), is not required in Latin American cities (Parra Herrera et al., 2017). Moreover, to include freight in urban plans, suitable indicators are needed. Thus, territorial intelligence and analytics, defined analogously to business intelligence and analytics, would add an important insight to urban planning, and allow freight to be correctly considered in urban planning and development actions. However, territorial intelligence and analytics remains as an emerging field, and freight transport is often not included in the proposed frameworks on the subject. Although some indicators and dashboards are proposed in the urban logistics literature (Melo and Costa, 2011; Gonzalez-Feliu and Morana, 2014; Morana and GonzalezFeliu, 2015), they are carrier-based and non-spatial explicitly in spatial indicators for urban freight, such as centrality, concentration, accessibility and attractiveness. Indeed, although proposed in research works, those indicators are not often used in urban logistics (Gonzalez-Feliu et al., 2018) since they are not always defined in the same terms and developed by different disciplines, as opposed to their analogous indicators for private transport. However, freight accessibility and similar indicators have a strong potential for urban planning (van Wee, 2016). 
The aim of this paper is to present an overview of spatial accessibility and attractiveness indicators for urban freight transport and logistics, from a territorial intelligence and analytics viewpoint, as well as to address the main issues and implications for an application in Latin American cities' urban planning and development. First, the main notions of business intelligence and analytics and territorial intelligence are presented. A formal definition of territorial intelligence and analytics is proposed, as well as a brief overview of the main categories of indicators related to territorial intelligence dashboards. Then, the state of the art in accessibility and attractiveness indicators in terms of urban freight transport and logistics is presented, proposing the categorization of said indicators, and the main formulations for accessibility and attractiveness estimation. The paper includes five categories of indicators and seeks to synthesize the different research works on the field that have indicators being assimilated into attractiveness or accessibility measures, and dealing explicitly with freight transport in urban areas or the activities that generate those transport flows. Afterwards, the main issues for implementing such indicators, in terms of data requirements and potential applications, are addressed in a global perspective. Finally, and focusing on Latin America, the main implications for the deployment of a territorial intelligence analytics vision of urban freight transport planning and management are presented.

\section{The potential and needs of an analytics-oriented territorial intelligence approach}

\subsection{From business intelligence and analytics to territorial intelligence analytics}

Business intelligence $(\mathrm{BI})$ is currently a main issue for companies around the world, and is also popular in research, especially in relation to decision and management sciences (Chen et al., 2012). Coined by Howard Dressner, analyst at the Gartner Group, in 1989 (Negash and Gray, 2008), it has become the dominant approach in company-based information business and management (Watson and Wixom, 2007; Turban et al., 2013). According to Negash and Gray (2008), business intelligence systems are computer-based systems that "combine data gathering, data storage, and knowledge management with analytical tools to present complex and competitive information to planners and decision makers." In computer-based environments, business intelligence uses large databases, typically stored in data warehouses, as main sources of information and the basis for sophisticated analysis, the so called "analytics", i.e. processes aiming at "developing actionable insights through problem definition and the application of statistical models and analysis against existing and/or simulated future data" (Cooper, 2012).

$\mathrm{BI}$ analytics tools are then based on data processing, statistics, artificial intelligence, combinatorial optimization and other advanced data production and analysis techniques to provide synthetic and "easy to visualize" results and indicators (Yogev et al., 2012). Those techniques are of a wide variety (Holsapple et al., 2014) and produce results 
such as simple reporting, slice-and-dice, drill down, answering ad hoc queries, realtime analysis, and forecasting, among others (Negash and Gray, 2008). Nowadays, many vendors provide $\mathrm{BI}$ analysis (and analytics) tools, which have a main common reporting instrument: the dashboard (Negash and Gray, 2008). Dashboards, which are used in many business and management issues, are managerial tools that support effect change diagnosis and steering in companies through the introduction of a set of indicators (physical, economic and financial, environmental, social, and/or transversal, among others), and present, analogously to a car's dashboard, in a graphic and "easy to read" way (Kerzner, 2017). According to Bouquin (2001), dashboards display a small set of indicators (five to ten) to support managers' decisions by making them become aware of the status and evolution of the systems they are monitoring, as well as to identify the trends in the system's behavior on a horizon relevant to the nature of their functions.

Dashboards are used in various fields of business and commercial activities, and are a common instrument in logistics planning and management, not only for controlling and monitoring but also as a dialog tool among the different supply-chain stakeholders (Morana, 2014). In urban logistics, dashboards are starting to be deployed in a unified way (Gonzalez-Feliu, 2018), by adapting the indicators of sustainable supply-chain management (Morana, 2014) to the urban logistics context, and in an interactive and group-decision perspective (Morana and Gonzalez-Feliu, 2015), since various stakeholders are involved. Indeed, in urban logistics, both public and private stakeholders of different nature and with different goals and action scopes interact to deploy solutions, with the aim to improve the logistics activities of the cities, mainly in a sustainability perspective (Gonzalez-Feliu, 2018).

Private stakeholders such as transport carriers, logistics providers, wholesale grocery distributors, and most shippers are used or are starting to be used as BI tools, at least in Europe and the USA'. They may have the potential in Latin America ${ }^{2}$, for example, to support the development of Sales and Operations Management approaches in import-export companies (Padilla Solís, 2014). The deployment of such systems on retailers, mainly on nanostores (Fransoo et al., 2017), seems to be more difficult, as well as the introduction of $\mathrm{BI}$ tools to support public authorities' management decisions,

1 Purposes given as a conclusion of a series of interviews granted to private companies in Europe between 2017 and 2018 (related to the ANNONA project financed by the French Agency of Research), and a private conversation with professors Eiichi Taniguchi, José Holguín Veras, Ron van Duin, and Jesus Muñuzuri in 2016 (during the ILS and VREF conferences).

2 Private conversations with logistics experts in Colombia and Peru in 2017 and 2018 showed that the field of BI remains preliminary in small companies, but its deployment has a non-negligible level of maturity in big companies in Latin America. However, most small logistics operators showed an interest on those systems. 
mainly related to urban logistics (Parra Herrera et al., 2017), which remain far from a BI logic. Anyway, in all cases, they seem to be favorable to the deployment of dashboards concerning urban logistics (Gonzalez-Feliu and Morana, 2014), although the definition of indicators and the decision-support systems that can be implemented for this purpose remains as a challenging research subject (Palacios-Argüello et al., 2016). Moreover, communication among all involved stakeholders in urban logistics (and more generally in urban transport) is essential to reach consensus and deploy satisfactory solutions that are sustainable and viable in a long time perspective (Ville et al., 2013).

At the land-planning level, the notion of territorial intelligence ( $\mathrm{TI}$ ) was defined in 1999 as "a means for the researchers, actors and territorial community to acquire a better knowledge of the territory, but also to better handle its development" (Girardot, 2000). The main aim of Tl, according to its initial definition, was to support territorial stakeholders (mainly belonging to local public administrations) to first understand the dynamics of their territory, and then plan, define, develop, and evaluate the policies and the actions of sustainable territorial development. Girardot (2009) links the notion of TI first to sustainable development and then to a whole range of multidisciplinary knowledge in the field of territory knowledge, territorial governance and territorial engineering (Chiasson et al., 2014; Barles, 2018). TI seems to remain mainly related to research (Bertacchini, 2004; Hebraux and Masselot, 2007; Bertacchini et al., 2007; Dumas et al., 2007 Crozet et al., 2012). Indeed, as opposed to BI which was created in the business context, $\mathrm{TI}$ is a notion generated in research (mainly associated to geography, planning and development) without an explicit link with analytics, and has difficulty to be appropriate in public administration practices without a strong support of research communities. However, various applications in the practice field using GIS and spatial statistics for planning purposes (Antoni, 2016) are close to what TI aims to address without using explicitly that term. Anyway, the notion of analytics and the use of BI techniques, mainly dashboards and data storage and processing capacities, are still not clearly formalized in classical TI approaches. These remain relying mainly on Geographic Information Systems (GIS) to visualize the information; however, they do not use, at least in a generalized way, advanced computing and analytics techniques (Hegron and Haxaire, 2012; Bertacchini and Desprez, 2016).

Finally, we observe that, if Bl is mainly related to business management systems (BMS) and relies on computer science and data processing and analysis techniques, $\mathrm{Tl}$ is systematically associated to GIS and is mainly related to geography and planning studies. However, in order to provide tools that are used by both planners and logistics managers, and feed debate and understanding (and then consensus) among all those stakeholders, the combination of $\mathrm{BI}$ tools with the logic of TI will lead to a powerful, reliable set of tools that is, at the same time, deployed in daily operations (on business side) and interact with land-planning actions (more often at middle- and/or long-term horizons, mainly on territorial side). 
For those reasons, it seems important to us to define territorial intelligence analytics as the (until now) missing link between $\mathrm{BI}$ and $\mathrm{Tl}$, which will then belong to both. In other words, we can define Territorial Intelligence and Analytics as the set of tools that combine data gathering, data storage, and knowledge management with analytical tools to spatially present complex and competitive information to planners and decision makers in terms of territorial decisions, and feed the interactions between planners and operational managers.

Territorial intelligence analytics tools will then rely on GIS not only to visualize information but also to retrieve and process it. Databases and data warehouses will then contain detailed spatial (mainly geolocated) information, and restitute aggregated indicators not at an individual or service level (like in classical BI systems) but at a zone or city level. As in BI and TI classical approaches, dashboards appear to be the most reliable and transferable output of territorial intelligence analytics.

Said dashboards need to be spatial-based, i.e. they are projected into a cartographic and/or zonal file. Moreover, they rely on a series of spatially-represented indicators. Some of them already exist in classical TI approaches, but others are less known at least in urban logistics. For that reason, we present hereinbelow an overview of those indicators by category, first in a general way and then focusing on urban logistics applications.

\subsubsection{Main types of indicators in territorial intelligence analytics}

According to the statements and definitions explained in the previous section, and analogously to business intelligence analytics and territorial intelligence indicators (from a land-planning viewpoint), we can distinguish three main categories of indicators that would be considered in territorial intelligence and analytics. These categories can be defined based on the principles of TI (which follow sustainable development issues) from a more spatial and territorial viewpoint (Masson and Petiot, 2012). As said above, territorial information systems would consider to include those categories of indicators synergically, and deploy them using spatial representations (mainly via GIS) to address the various stakeholders susceptible to use them. The main categories of indicators can be derived from the three spheres of sustainable development, which are also used in sustainable supply chain management and sustainable urban logistics decision support (Morana, 2014; Gonzalez-Feliu, 2018):

- Economic indicators will account for economic (and socio-economic) issues of the territory. 
- Environmental indicators will show the impacts of land use and territorial development in natural resource consumption, climate change, and environmental issues.

- Socio-spatial indicators will address socio-demographic issues, as well as inequalities among populations related to territorial decisions and actions.

We present below a brief description of each category, and show the main indicators used in urban logistics related to territorial intelligence and analytics.

\subsubsection{Economic indicators}

Whereas in business intelligence the main economic indicators will focus on sales, income, margins, and stocks, among others (Chissera et al., 2018; Laursen and Thorlund, 2016), main economic indicators in territorial intelligence address spatial economics issues (Dima, 2016; Kourtit and Nijkamp, 2018). For those reasons, sociodemographic indicators (characterizing the population and the employments) are mainly used (Kourtit and Nijkamp, 2018). Land use costs (primarily acquisition or rental), population income, or investment costs of infrastructures and services can also be used (Dima, 2016). In general, territorial intelligence analytics will use socio-economic indicators, integrating at the same time an economic and social dimension (Barrientos et al., 2018).

Concerning urban logistics, the main indicators used in both research and practice, from a territorial intelligence analytics viewpoint, are related either to the cost of zonal logistics activities or to the characteristics that have an impact on logistics demand generation (see section 3.3 for more information, since those elements can be related to attractiveness and accessibility), such as the number of establishments or employments (Holguín-Veras et al., 2018).

Other indicators that can be defined at a spatial level are congestion levels, number of vehicles (by type), with their respective average loading rates and use rates of warehouses and platforms, among others (Melo and Costa, 2011; GonzalezFeliu, 2018). 
Table 1. Main economic indicators for urban logistics in a territorial intelligence analytics perspective (author's elaboration from works cited above)

\begin{tabular}{|l|l|l|}
\hline Impact subcategory & Impact indicator & Unit $^{3}$ \\
\hline \multirow{3}{*}{ Flow intensity } & Road occupancy rates & Km vehicle CEU \\
\cline { 2 - 3 } & Freight flow intensity & Tons km \\
\cline { 2 - 3 } & Number of vehicles (per type) & Vehicles (per type) or CEU \\
\hline \multirow{2}{*}{ Time } & Total transport times & Hours \\
\cline { 2 - 3 } & Total stop times (road occupancy by stopped vehicles) & Hours vehicle CEU \\
\hline \multirow{3}{*}{ Cost } & Transport cost of considered routes & $€, \$$, other monetary value \\
\cline { 2 - 3 } & Land use costs & $€, \$$, other monetary value \\
\hline
\end{tabular}

\subsubsection{Environmental indicators}

Main environmental indicators are related to either global warming or pollution. Global warming indicators are often expressed in greenhouse gas emissions (GHG emissions) in $\mathrm{kg}$ or tons of $\mathrm{CO}_{2}$ equivalent (Dodman, 2009). They are generally nonspatial since global warming is counted at a general scale (related to a city or area), but can be represented at a zone level to show which are the zones that produce more GHG emissions (Guzmán-Jiménez et al., 2014). Moreover, GHG are commonly related to an activity of the city, like household (primarily related to heating and energy consumption), industry, retailing and service activities, transport (private and/ or freight transport), etc. A similar reasoning is shown for energy consumption and pollution emissions, which can be related to the potentially-polluted environment, i.e. water, soil or air, and represented either by the producing source or the main deposit zone of that pollution. Different pollutants can be estimated (Norman et al., 2006; François, 2015) and, in that case, indicators are also declined by activity or product.

In all instances, different approaches for estimating pollution can be observed. In general, two main categories of approaches are used: direct emission models and methods aimed to estimate the environmental impacts directly generated by a system, and lifecycle analyses that propose to examine the lifecycle of a product or process to estimate both direct and indirect impacts (Norman et al., 2006; Andriankaja et al., 2015). The main environmental indicators that can be used in urban logistics from a territorial intelligence analytics viewpoint are reported in table 2 .

3 Indicators are presented at a zone level and mainly cartographically when dealing with territorial intelligence and analytics.

4 Car equivalent unit on the following basis (Gonzalez-Feliu, 2018): 1 private car or van = 1 ECU, 1 light commercial vehicle $=1.5 \mathrm{ECU}, 1$ single truck $=2 \mathrm{ECU}, 1$ articulated truck $=2.5$ to $3 \mathrm{ECU}$. 
Table 2. Main environmental indicators for urban logistics from a territorial intelligence analytics perspective (adapted from François, 2015 and Andriankaja et al., 2015.)

\begin{tabular}{|l|l|l|}
\hline Impact indicator & Unit & Substances \\
\hline Global warming emissions & $\mathrm{kg} \mathrm{CO}$, eq. & All greenhouse gases \\
\hline Terrestrial acidification emissions & $\mathrm{kg} \mathrm{SO}_{2}$ eq. & $\mathrm{NH}_{3}, \mathrm{SO}_{2}, \mathrm{NO}_{\mathrm{x}}$ \\
\hline Photochemical oxidant formation index & $\mathrm{kg} \mathrm{NMVOC} \mathrm{eq.}$ & Non-methane volatile organic compounds (NMVOC) \\
\hline Particulate matter formation index & $\mathrm{kg} \mathrm{PM10} \mathrm{eq.}$ & $\mathrm{PM} \mathrm{SO}_{2}, \mathrm{NO}_{x^{\prime}} \mathrm{NH}_{3}$ \\
\hline Fossil depletion potential & $\mathrm{kg} \mathrm{oil} \mathrm{eq.}$ & Coal, gas, oil \\
\hline Metal depletion potential & $\mathrm{kg} \mathrm{Fe} \mathrm{eq.}$ & All metals \\
\hline \multirow{2}{*}{ Energy consumption indicators (fossil and renewable) } & MJ eq. (fossil) & Coal, gas, oil, nuclear, wood \\
\cline { 2 - 3 } & MJ eq. (renewable) & Hydro, wind, geo, solar, biomass \\
\hline
\end{tabular}

\subsubsection{Social and spatial indicators}

Pure social indicators are the less developed ones in territorial intelligence, since most social issues are generally related to economic (as said above, various economic indicators address socio-economic issues) and/or environmental impacts (for example, employment changes, congestion or noise), or they present as qualitative issues (such as life quality or inhabitant satisfaction, among others). However, other socio-economic issues can also be addressed via spatial indicators, such as inequality, accessibility, attractiveness or resilience (Metzger et al., 2015). Those specific socio-spatial issues, although very popular in private transport and land planning (Antoni, 2016), remain unused for urban logistics, at least when dealing directly with territorial intelligence analytics.

However, measures and indicators that can be assimilated to accessibility and attractiveness are commonly used in other fields and with other uses. Indeed, the literature has a plethora of works and examples using indicators related to urban freight transport and logistics that either are defined as accessibility measures or represent that accessibility. However, it is difficult to identify and characterize them since they belong to different disciplines and applications. For that reason, we propose in the next section an overview of freight accessibility indicators with an urban and/or periurban scope.

\section{Accessibility-based spatial indicators for urban logistics territorial intelligence analytics}

The notion of accessibility is widely used in transport planning and urban development, at both research and practice levels. Moreover, it can also have industrial applications 
(Gonzalez-Feliu et al., 2018). Accessibility is defined by Geurs and van Wee (2004) as "the extent to which land-use and transport systems enable individuals to reach destinations by means of a transport mode," and remains, at least in transport and land planning, mainly related to private transport (van Wee, 2016). However, specific freight accessibility is not only a challenging subject in research but has real applications and issues in practice (van Wee, 2016). Despite this, the literature in urban studies (the main field addressing accessibility) has few works addressing freight accessibility explicitly. However, works proposing indicators that represent that accessibility can be found in various disciplines but, since they do not use the same terms and notations, such analyses are not always identified and related to freight accessibility.

We present herein a first attempt to systematically show the main approaches to define accessibility and attractiveness indicators from different viewpoints and perspectives. Attractiveness can be defined as a reciprocal measure to accessibility: according to GonzalezFeliu and Peris-Pla (2017), attractiveness can be defined as the measure "that estimates the ability of people and/or goods to reach a given destination from each possible origin." In other words, if accessibility is observed for each origin, attractiveness is observed for each destination. Due to these reasons, we can mainly use the same approaches to define either attractiveness or accessibility; the difference will lie on the aggregation focus: the origin of trips for accessibility, and the destination for attractiveness.

The main issue of a good indicator (from a problem-solving viewpoint, Ackoff, 1977) is to represent the suitably of this ability to reach (a destination) or be reached (from an origin). We have observed in the literature a variety of indicators and approaches. To propose a categorization, we start by examining how private transport accessibility has been defined and organized, since it is a field with more than 50 years of existence (van Wee, 2016). Private transport accessibility indicators are in general divided into three main groups (Gonzalez-Feliu et al., 2014b):

- Infrastructure (or service) indicators state at the service level related to a transport infrastructure. The main examples of infrastructure-based accessibility indicators are congestion levels and average travel speeds on a road network (Geurs and van Wee, 2004), and are related to traffic analyses. Although traffic analyses can explicitly integrate freight flows, they remain being oriented to private transport with respect to service-level measures.

- Location-based measures describe the level of accessibility to spatially distributed activities. Two main groups of indicators can be distinguished in this category: distance-based indicators (Ingram, 1971; Pirie, 1979) and gravity accessibility measures (Stewart, 1947; Hansen, 1959).

- Person-based measures define accessibility at the individual level (Burns, 1979). Such indicators can be derived from space-time geography theory (Hägerstrand, 
1970; Miller, 1999; Recker et al., 2001) or be based on the concept of utility (BenAkiva and Lerman, 1979; Martinez, 1995). Geurs and van Wee divide this category in two but, since those indicators are person-based and related to behavior and/or time budget issues, they seem not suitable for an adaptation to freight.

Freight accessibility is less standardized in research than accessibility related to private transport (Gonzalez-Feliu, 2012), with few works being appointed in general accessibility reviews (Geurs and van Wee, 2004; van Wee, 2016). Indeed, although works of different nature and disciplines address freight accessibility (Gonzalez-Feliu, 2012), they remain unknown for transport and land use stakeholders (van Wee, 2016). However, the inclusion of freight in accessibility has recently been appointed as necessary and having a strong potential for future works (van Wee, 2016; Gonzalez-Feliu et al., 2018a, 2018b).

To examine how those indicators can be deployed in urban logistics, we followed a document selection and analysis method based on the lexical-metanarrative literature review framework of Gonzalez-Feliu (2013). We started from a core set of papers (issued from the main references on freight accessibility cited by Gonzalez-Feliu, 2012 and van Wee, 2016, as well as from papers issued after a keyword-based search on Web of Science, Scopus, and Google Scholar 5 ).

Then, via snowballing techniques and exchanges with researchers working in the fields of urban planning, transport, and logistics, other papers which address the notions of urban freight accessibility and attractiveness were selected. To that end, the main metanarratives followed the notion of freight accessibility (and freight attractiveness) as defined above. In other words, papers addressing measures related to those definitions, even not using those terms, were selected. Synonymous notions such as centrality, concentration, catchment area, attraction, production, or logistics potential were considered to select papers and works. Later, a first set of indicators could be related to urban freight accessibility and attractiveness, and a second round of document search was made, mainly using citations of citations and Google Scholar on precise terms that follow the considered metanarratives. It is important to note that, as opposed to other systematic literature review techniques, this method is not limited to documents on a database, but extends the search to most research documents including grey literature (Gonzalez-Feliu, 2011, 2013). Finally, 124 documents were selected: 52 research papers published in peer-review journals, 5 literature review papers published in peer-review journals, 28 conference papers, 9 scientific books, 11 book chapters, 4 PhD

5 The terms used for the keyword-based search were "freight accessibility" AND urban; "freight attractiveness" AND urban; "freight transport" AND accessibility AND urban; "freight transport" AND attractiveness AND urban. According to the metanarrative literature review methodology (Gonzalez-Feliu, 2011), a pre-selection of those papers is made by verifying that the main scope of the paper is related to that of the literature review, i.e. that the papers address issues of spatial accessibility and attractiveness regarding freight transport in urban areas. 
theses, and 15 other grey literature documents ( 3 Master's theses, 8 research reports, and 4 communications from invitations to conferences and seminars).

From those works, we observe that the terms and notations used in the definition of accessibility and attractiveness indicators are different and obey to disciplinary issues. However, a typology of indicators can be defined, grouping them by their similarity in terms of the physical notion used to define accessibility and the variables used to explain it.

Therefore, we propose a typology of accessibility (and attractiveness) indicators that define 5 categories of measures:

- Infrastructure or service level indicators

- Freight generation-based indicators

- Distance and cost accessibility indicators based on route construction

- Gravity indicators

- Compatibility accessibility measures

\subsection{Infrastructure or service level indicators}

Infrastructure accessibility indicators measure the service levels of infrastructures; and, in the case of freight indicators, they need to refer explicitly to goods transport and logistics activities. Since we can define two types of infrastructures (Gonzalez-Feliu et al., 2014a), i.e. nodal and linear (or edge-based), we can expect two types of infrastructure freight accessibility. Nodal accessibility will refer to nodal infrastructures, i.e. logistic platforms and terminals, as well as loading/unloading area availability and capacity. Edge accessibility will refer to linear (or edge) infrastructures, i.e. roads, railways and fluvial lines, and will define capacities and service levels. Since roads (and streets) are in general used for private transport, public (or collective) transport of people, and freight/ goods transport, it is difficult to propose a "unique private transport" or a "unique freight transport" indicator. Nevertheless, we can define person-oriented or freight-oriented indicators, i.e., those which focus on one of the two main segments of urban transport.

\subsubsection{Nodal indicators}

Nodal indicators are the most difficult to identify, since they are not generally presented under the banner of "accessibility". However, service levels and capacities of logistics infrastructures can be accessibility indicators, mainly when presented in a spatial form. Those capacity and service indicators are often shown at an individual level or for interurban and international transport (Liu and Ma, 2005; Li et al., 2015). 
However, logistics capacities can be estimated at a zone level for cities (Avelar-Sosa et al., 2014), generating a first nodal accessibility indicator (the logistics capacity of a zone can be a proxy variable of the accessibility of its logistics infrastructure).

Another indicator related to accessibility is that of the delivery space capacity and availability. Delivery bay capacity and availability indicators are needed in practice, mainly for delivery area planning (Dablanc and Beziat, 2015). Some public authorities conducted studies to define the needs of delivery bay resources (via freight trip generation or FTG models, Holguín-Veras et al., 2012, Gonzalez-Feliu, 2018), estimating the current capacity and determining a service level of delivery bays (CERTU, 2009). However, most works related to delivery bay planning are based on logistics organizations and routing/fleet management issues (Patier et al., 2014; Comi et al., 2017), and not on bay capacity and service level, which is essential to make new projects of this nature be economically viable (Gonzalez-Feliu et al., 2013a, 2014c). However, some works deal with the spatial clustering of areas to define the "service level" and capacity of the delivery bay system of a city or conurbation (Magniol et al., 2018).

Service levels of logistics infrastructures (Rafele, 2004), expressed in terms of service key performance indicators or KPI (Morana, 2014), can also be considered as accessibility indicators, although to the best of our knowledge they remain related to individual logistics platforms or plants, or are aggregated at a regional or national level (Yang et al., 2009). Anyway, this type of indicators seems suitable to be adapted to periurban or urban zones in order to define a service-level nodal accessibility indicator.

\subsubsection{Edge indicators}

Edge indicators can be related to road, fluvial or railway infrastructures (air and sea are not examined herein since we focus on urban and periurban areas, and they would be considered in a general freight accessibility for interurban and international transport). However, fluvial and rail capacity estimation in urban areas remains little studied, but methods to estimate the capacity (in the number of vehicles or available travel times) of railway (Pavone, 1997; Laroche, 2014; Troch et al., 2017) and fluvial (Lendjel and Fishmann, 2014) infrastructures can be determined at an urban, periurban or local (i.e. less than $150 \mathrm{~km}$ from main cities) level when it relates to urban logistics. In general, capacity estimation of such infrastructures is deterministically or probabilistically expressed in the number of vehicles (by time interval) that can circulate on those infrastructures (de Kort et al., 2003; Abril et al., 2008). This is inferred knowing that, as opposed to roads where the use of the infrastructure is open and submitted to equilibrium principles, the use of the 
infrastructure in railways is regulated (Laroche, 2014). Fluvial infrastructures follow a mixed logic, with main flows being regulated. However, touristic and private transport flows can enter the system but remain in the minority in most cases). Road accessibility indicators are mainly related to network load and capacity (so to road service levels). Capacity indicators are related to road planning and dimensioning, and are primarily used to define the limits and needs of transport planning and management actions linked to master plans or transport-land use actions (Yachiyo Engineering Co. Ltd. and Pacific Consultants International, 2005).

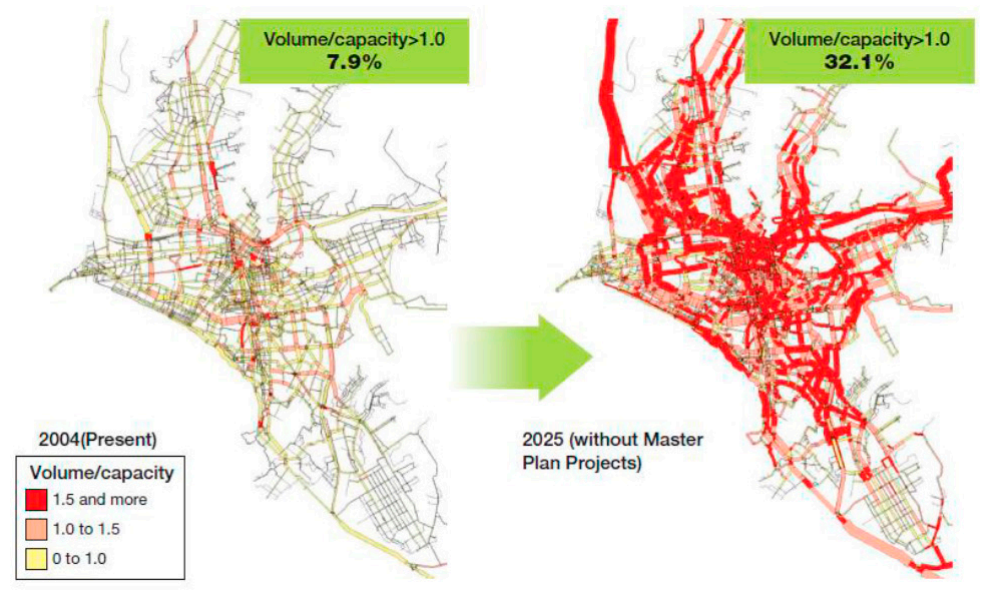

Figure 1. Volume/capacity ratio of road infrastructures for the city of Lima in 2004 and forecast for 2025 (Yachiyo Engineering Co. Ltd. and Pacific Consultants International, 2005)

Service level indicators derive from traffic dynamics and analysis, but we present herein the works which explicitly consider trucks in the definition of indicators (Chiabaut et al., 2015), with the aim of considering the inconvenience caused by freight vehicles in double parking (Chiabaut et al., 2016; Lopez et al., 2016; Lopez, 2017), or the difficulties of accessing to urban highways and high-capacity road infrastructures (Wang et al., 2016). Those works propose in general an adaptation of macroscopic flow diagrams to include truck traffic and truck impacts in general traffic. They indicate the traffic load, and indirectly the travel speed, related to double-line parking of trucks and/or the congestion caused by those trucks when they are in difficult maneuver situations related to road capacity reduction (in number of lines) or access (crossroads, intersection lines, road accesses) to those infrastructures. Other aggregated indicators are those of average congestion reported on a dashboard perspective (i.e. in a color code from "very good" to "very bad"), and according to the number and type 
(in terms of capacity) of the road infrastructures. Said accessibility can then be grouped by zones using, for example, clustering techniques to identify homogeneous zones in terms of traffic congestion (Metzger et al., 2015; Lopez, 2017).

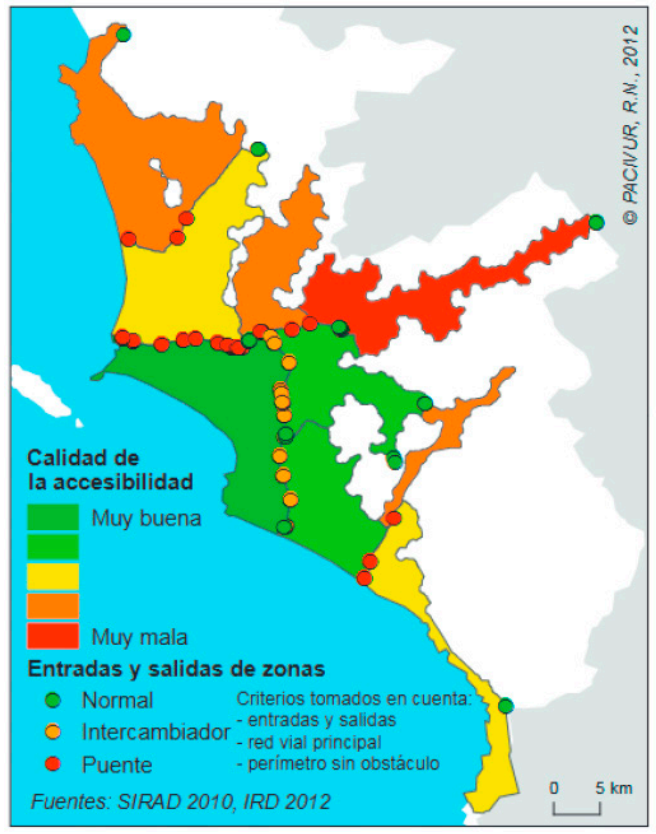

Figure 2. Service level edge accessibility (related to congestion and capacity of road infrastructures) for the city of Lima in year 2010 (Metzger et al., 2015)

Finally, a simple and "easy to assess" edge indicator is that of average (or geometric mean) speeds of infrastructures (Pluvinet et al., 2012), by infrastructure type, obtained empirically from survey data (Ségalou et al., 2004; Béziat, 2017), and from GPS data collection procedures (Gonzalez-Feliu et al., 2013b). It can also be estimated via modeling techniques and/or probabilistic estimation (Wang et al., 2016, 2017), among others.

\subsection{Freight generation determinants and rates as an accessibility indicator}

An interesting indicator that can be related to attractiveness is that of the potential of a zone's logistics demand, which can be defined by a logistics demand index (Zhao, 2010), or more generally that of logistics demand generation rates, since zones of higher demand may be considered more attractive zones for logistics purposes. Whereas infrastructure- 
based indicators show capacity or service levels (in other words, they characterize the logistics supply of spatial areas), indicators presented in this category characterize demand as an attractiveness measure. Logistics demand can be expressed in terms of freight quantities to be shipped/delivered (Cai and Chen, 2004), number of shipments or deliveries (Guilbaut and Gouvernal, 2010), or number of trips (Holguín-Veras et al., 2011). In general, the last two may be directly related (Gonzalez-Feliu, 2019).

Freight trip and freight generation can be defined at the level of inbound trips (i.e., only receptions or deliveries represented in attraction models), outbound trips (pickups or expeditions, represented in production models), or both types of flows together (without distinguishing them). Those estimations can also be considered as a nodal accessibility measure or zonal accessibility measure, when defined in zones. For that purpose, Holguín-Veras et al. (2018) perform an international comparison of cities based on freight trips, showing that this type of measures may be a good proxy of accessibility (or attractiveness) to compare cities and areas in terms of logistics needs and opportunities. Other works propose a spatial view of freight generation and freight trip generation, defining zone profiles in terms of freight needs (Lawson et al., 2012; Sanchez-Diaz et al., 2013; Ducret and Gonzalez-Feliu, 2016; Gonzalez-Feliu and Peris-Pla, 2017).

At an individual level, freight trip generation rate $\pi_{i j}^{k}$ of establishment $j$ belonging to class $k$ and in zone $i$ are mainly defined as follows:

$$
T_{i j}^{k}=f^{k}\left(\text { Emp }_{j} ; \text { Area }_{j}\right)
$$

Where $E m p_{j}$ and Area $_{j}$ are respectively the number of employees and the area of establishment $j$.

In the same way, the freight generation rates of establishment $j$ belonging to class $k$ and in zone $i$ are mainly defined as follows:

$$
Q_{i j}^{k}=f^{k}\left(\text { Emp }_{j} ; \text { Area }_{j} ; \text { Revenue }_{j}\right)
$$

Where Revenue is the total income of establishment $j$. The functions can be linear or non-linear, and each function is specific for a category. In other words, the variables and functional forms are different for each category (Gonzalez-Feliu and Sanchez-Diaz, 2018a)

At a zone level, we can estimate the FTG and FG rates by aggregation of individual rates, i.e. of trips generated by each establishment. In other words, given a zone $i$, the number of freight trips $T_{i}$ and the freight quantity $Q$ generated by the zone can be estimated as follows: 


$$
\begin{gathered}
T_{i}=\sum_{k=1}^{m} \sum_{j \in V_{i}^{k}} T_{i j}^{k}=\sum_{k=1}^{m} f^{k}\left(E s t_{i}^{k} ; \text { Emp }_{i}^{k} ; \text { Area }_{i}^{k}\right) \\
Q=\sum_{k=1}^{m} \sum_{j \in V_{i}^{k}} Q_{i j}^{k}=\sum_{k=1}^{m} f^{k}\left(E s t_{i}^{k} ; \text { Emp }_{i}^{k} ; \text { Area }_{i}^{k} ; \text { Revenue }_{i}^{k}\right)
\end{gathered}
$$

Where $V_{i}^{k}$ is the set of establishments of category $\mathrm{k}$ in zone $i$, and $T_{i j}^{k}$ is the number of freight trips of establishment $j$ belonging to set $V_{i}^{k} ; E s t_{i}^{k}, E m p_{i}^{k}$, Area $_{i}^{k}$ and Revenue $_{i}^{k}$ which are respectively the number of establishments, number of employees, total area, and total revenue of all establishments of category $k$ inside zone $i$. In other words, demand attraction indicators can be defined either at an individual level and then at a zone level via aggregation, or specifically with zonal models.

A basic accessibility or attractiveness indicator derived from freight or freight trip generation is issued from the normalization of zonal FTG or FG rates, estimated analogously to the basic measure of centrality in real estate studies (Kauko and d'Amato, 2009). Given an urban area $U A$ divided in zones, the generation-based relative accessibility or attractiveness $A_{i}$ of zone $i$ can be then formalized as follows:

$$
A_{i}=K \cdot \frac{F T G_{i}}{\operatorname{Max}_{i \in U A}\left(F T G_{i}\right)} \text { in terms of freight trips }
$$

Or

$$
A_{i}=K \cdot \frac{F G_{i}}{M a x_{i \in U A}\left(F G_{i}\right)} \text { in terms of commodity quantities }
$$

Where FTG and FG are estimated as shown above: when using FTG or FG rates, this indicator considers both attracted and produced trips (and freight quantities). Note that FTG can be replaced by FTA (in this case, the indicator will be attractiveness) or by FTP (for a pure accessibility indicator).

Another interesting indicator is the density of freight trips (or deliveries) or the freight generation density, obtained respectively by reporting FTG and FG rates to each zone's surface (or area):

$$
D_{i}^{F T G}=\frac{F T G_{i}}{S_{i}} \text { or } D_{i}^{F G}=\frac{F G_{i}}{S_{i}}
$$


Where $S_{i}$ is the surface (or area) of zone $i$. As for the previous indicator, this density can be estimated in terms of attraction (FTA, FA), production (FTP, FP) or combined (FTG, FG) rates.

A more advanced indicator which can also be associated with generation-based accessibility and attractiveness, although not initially proposed for this purpose, is that of concentration of industrial and logistics activities (Marcon and Puech, 2009). Indeed, since freight-intensive sectors like industry, wholesaling and logistics result in high-logistics needs (Holguín-Veras et al., 2018), defining a measure of concentration can lead to a suitable attractiveness or accessibility indicator in urban logistics. Said concentration can be measured as the proportion of such activities within a sector, where distance is smaller than a given threshold of the same proportion in the entire urban area, and can take different forms (Ripley, 1977; Marcon and Puech, 2003; 2009; Duranton and Overman, 2005, 2008). The concentration index $\operatorname{Con}_{r}^{S}$ of industrial and logistics activities in sector $r$ (with respect to a threshold $r$ ) can be formalized as follows:

$$
\operatorname{Con}_{r}^{S}=\frac{P\left(\left|x_{i}^{S}-x_{j}^{S}\right| \leq r\right)}{\operatorname{Den}\left(N, N^{S}\right)}
$$

Where $P\left(\left|x_{i}^{S}-x_{j}^{S}\right| \leq r\right)$ is a probability (or statistical density) function defining the proportion of couples of activities in sector $S$, in which distance is smaller than $r$, and $\operatorname{Den}\left(N, N^{S}\right)$ is a density function of the number of activities $N^{S}$ in sector $S$, and the total number of activities in the given urban area is $N$. Those functions can take various forms and involve eventually other variables (Marcon and Puech, 2009).

\subsection{Distance, time and cost accessibility indicators based on route construction}

In this third category, accessibility is seen as the "cost" of reaching a zone (for freight transport purposes) from another zone of a city. To that end, three measures can be identified and used:

- Travel distance, either in an interzonal linking logic or from a route viewpoint.

- $\quad$ Travel or transport time, including or not loading and unloading service time.

- Transport cost, from a freight-transport viewpoint.

The most common and traditional indicator, as in private transport, is distance, which associates in each zone the average distance with a logistics service (Thomas et al., 2003; Rodrigue, 2004; Bowen, 2008; Rodrigue and Notteboom, 2010; Dablanc and Rodrigue, 2014). A variant of that indicator is the application of time accessibility indicators to logistics platforms (van der Heuvel et al., 2014). Accessibility indicators of this type mainly have the following form: 


$$
A_{i}=\operatorname{Average}\left(X_{i j}\right)
$$

or

$$
A_{i}=\operatorname{Min}\left(X_{i j}\right)
$$

Where $X_{i j}$ is a variable that measures the gap (in terms of distance, time or cost) between zone $i$ and any logistics service $j$. Those accessibility measures can also be reported from a spatial dashboard viewpoint (i.e. by reporting various accessibility classes, from low to high values, in a map in various spatial representation ways).

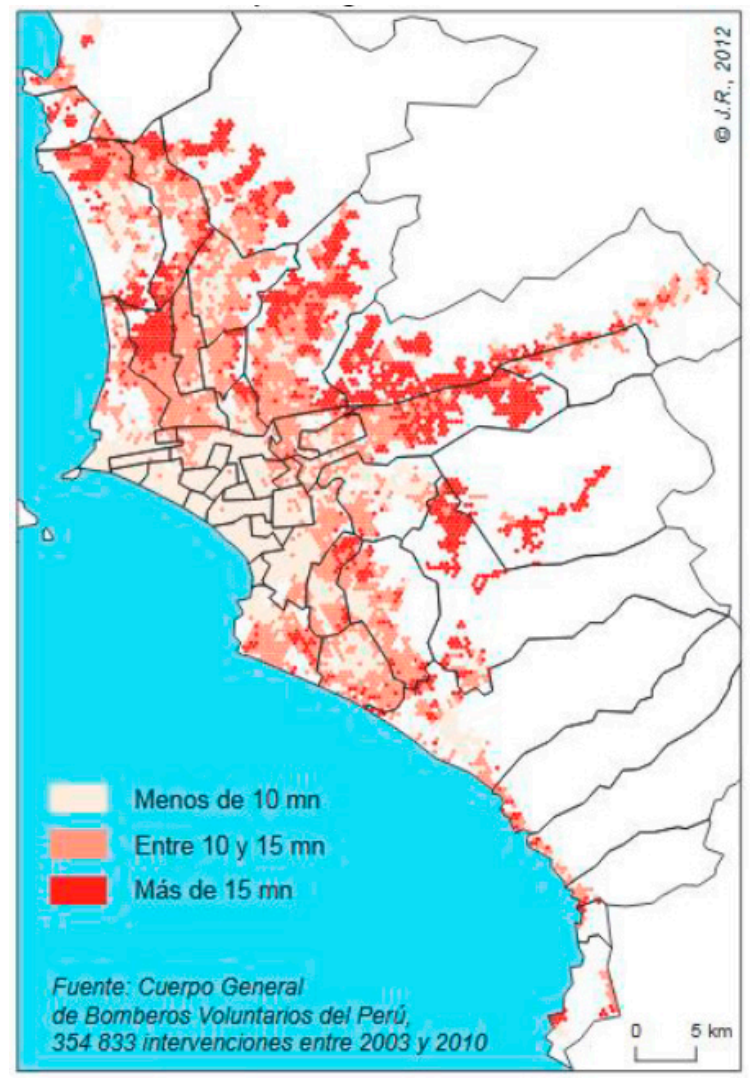

Figure 3. Firemen accessibility (in categories of travel time) in the city of Lima (Metzger et al., 2015)

Gonzalez-Feliu and Salanova Grau (2014) and Gonzalez-Feliu et al. (2014) propose an alternative indicator which is based on the estimation of routes (and not on the basis of direct transport between centroids as in other methods) to calculate travel distance 
and costs, and then estimate an accessibility indicator which is in general inversely proportional to those distances (Gonzalez-Feliu and Salanova Grau, 2014) or costs (Gonzalez-Feliu et al., 2014b). The distance (or cost) accessibility $A_{i}$ of a zone $i$ can be determined as follows:

$$
A_{i}=f\left(d r_{i} ; r_{i}\right)
$$

Where $d r_{i}$ is the total traveled distances of routes traveling and/or delivering inside zone $i$, and $t r_{i}$ is the total transport time (including both travel and service times) of routes acting inside zone $i$. Then, those distances can be estimated in two main ways (GonzalezFeliu, 2018):

- In a disaggregated way, via vehicle routing approaches (Cattaruzza et al., 2017) or microsimulation (Wisetjindawat and Sano, 2003).

- In an aggregated way, either using analytical models (Daganzo, 2005; Combes, 2016) or empirical approaches (Gonzalez-Feliu and Morana, 2014; Gonzalez-Feliu and Battaia, 2017).

\subsection{Gravity indicators}

Gravity-based accessibility is one of the most popular accessibility indicators in private transport (Geurs and van Wee, 2004), and remains as one of the most promising indicators also for freight transport in urban areas (Helling, 1998; Crainic et al., 2010; Gonzalez-Feliu, 2012; Giuliano et al., 2016; Gonzalez-Feliu et al., 2018). Gravity accessibility is defined, from the seminal work of Hansen (1959), analogously to gravity models and can mainly take two functional forms: a potential or an exponential one. The potential accessibility index can be defined as follows (Giuliano et al., 2010):

$$
A_{i}^{P}=\sum_{j=1}^{n} O_{j} \cdot f\left(c_{i j}\right)
$$

Where $\quad O_{j}$ is the opportunities to reach the zone of destination $j$.

$$
c_{i j} \text { is the cost of reaching zone } j \text { from zone } i \text {. }
$$

$$
f\left(c_{i j}\right) \text { is an impedance of } c_{i j} \text {. }
$$

Other functions of $\operatorname{cost} c_{i j}$ can be defined analogously to gravity models:

$$
A_{i}^{P}=K \cdot \sum_{j=1}^{n} O_{j} \cdot c_{i j}^{-\alpha}
$$


Where $\quad O_{j}$ is the opportunities to reach the zone of destination $j$.

$c_{i j}$ is the cost of reaching zone $j$ from zone $i$.

$\beta$ is the impedance parameter defined empirically or analytically.

$K$ is a constant.

$$
A_{i}^{E}=K \cdot \sum_{j=1}^{n} O_{j} \cdot e^{-\beta d_{i j}}
$$

A variant of the potential accessibility is that of the exponential accessibility, defined for urban goods transport as follows:

Where $\quad O_{j}$ is the opportunities to reach the zone of destination $j$.

$c_{i j}$ is the cost of reaching zone $j$ from zone $i$.

$\beta$ is the impedance parameter defined empirically or analytically.

$K$ is a constant.

The opportunities are related to the demand of logistics services (in general delivery or pickup needs) and can be related to freight quantities to deliver (Gonzalez-Feliu, 2008b, 2012; Crainic et al., 2010) to the number of establishments (Giuliano et al., 2016) or to the employment at the destination zone. Costs can be defined in terms of Euclidean distance (Crainic et al., 2010), average travel distance (Gonzalez-Feliu, 2018), peak travel time (Helling, 1998), generalized travel time (Gonzalez-Feliu and Mercier, 2013) or travel cost (Gonzalez-Feliu, 2019).

\subsection{Compatibility and flexibility accessibility measures}

Although personal measures seem not suitable for freight accessibility (since freight flows are organized in routes and schemes that imply systematic behaviors and choices related directly to the modes of management and of distribution for given commodities), it is possible to define indicators that associate space and time, not in terms of proximity but in terms of compatibility. Indeed, two close zones cannot be compatible for freight delivery purposes if time restrictions are applied to them, and travel times between them do not allow satisfying all deliveries in both zones (Gonzalez-Feliu, 2008a).

Some measures of compatibility in freight transport have been defined, which are mainly related to vehicle routing (Toth and Vigo, 2014; Cattaruzza et al., 2017) or driver scheduling optimization (Fischetti et al., 2001). The compatibility between two delivery requests $R_{i}$ and $R_{j}$ (required in a fixed location at given time intervals) can be defined as a binary attribute with 
a value that equals 1 if a feasible route that visits the destination point of request $R_{i}$ before serving request $R_{j}$ exits; otherwise, it takes the value of 0 (Fischetti et al., 2001). This attribute may support identifying which request $R_{i}$ can be served consecutively or not before request $R_{j}$ with the same vehicle, but remaining as an individual measure in relation to a single route and/or vehicle. Amico (2005) extends this notion into that of compatibility time interval (CTI) of a pair of requests $R_{i}$ and $R_{j^{\prime}}$ defined as the interval between the earliest arrival time and the latest arrival time at $R_{i}$ to deliver consecutively $R_{i}$ and $R_{j}$ in this order. Three stages can be defined regarding compatibility between two requests $R_{i}$ and $R_{j}$ (Gonzalez-Feliu, 2008a):

- Pair compatibility, when both $R_{i}$ and $R_{j}$ can be delivered without waiting time.

- Early incompatibility, when both $R_{i}$ and $R_{j}$ can be delivered but the vehicle arrives to location $j$ too early to deliver, so it needs to wait or include other deliveries between $R_{i}$ and $R_{j}$.

- Late incompatibility, when if $R_{i}$ is delivered, the vehicle arrives too late to location $j$, so it cannot deliver $R_{j}$.

Finally, various aggregates can be defined from individual compatibilities to define zonal indicators, like average values of each of those three compatibilities and incompatibilities (Amico, 2005) or more advanced indicators (Deflorio et al., 2012). Some of them are:

Average Compatibility Time Interval (ACTI), which represents the average value of all the positive pair compatibilities, and contains also a CTI from and to the depot (Amico, 2005):

$$
A C T I=\frac{\sum_{C T I_{A / B}>0} C T I_{A / B}}{n_{S}^{+}}
$$

Percentage of positive compatibilities in a zone (PPC, as in Amico, 2005):

$$
P P C=\frac{\text { numberofpositiveCTI }}{\text { numberofelementsinRCM }}(\%)
$$

Average of the Minimum Time Between each request $A$ and any Compatible Request B (AMTBCR, as in Deflorio et al., 2012):

$$
A M T B C R=\frac{\sum_{A} \min _{C T I_{A / B}>0}\left(t_{A B}\right)}{n_{R}}
$$

$A C T I$ quantifies the average compatibility time intervals between the requests, $P P C$ shows the proportion between positive and negative compatibilities, and AMTBCR gives 
an estimate of the time required to connect two requests in a plan. Those indicators based on the compatibility are calculated for pairs of requests, so they give an initial idea of how the request configuration fits on the network features.

Other indicators related to time access restrictions are also defined in the literature, mainly in terms of cost or distance indicators (which would be classified into the category of cost accessibility), such as in Quak and De Koster (2009), and Muñuzuri et al. (2013), or distance indicators, such as in Gonzalez-Feliu et al. (2015).

\section{Deployment of accessibility indicators in territorial intelligence analytics: \\ Implications for Latin America}

\subsection{Implementing urban freight accessibility and attractiveness indicators in a territorial intelligence analytics perspective}

We have seen above that freight accessibility and attractiveness indicators can take different forms and will then need processed data. Those indicators have different uses, related to the stakeholders, planning horizons, and data needs that are involved in their deployment.

Infrastructure-based indicators depend mainly on logistics capacities and service levels in the case of nodal accessibility (which are given at individual level although mean values can be given by some public authorities and/or chambers of commerce and industry), and need traffic data for edge accessibility. Nowadays, mapping and itinerary websites, such as Google Maps, Bing Maps or Open Street Maps, have average congestion charging data on most road links of cities (some of them at different time slots), allowing the estimation of congestion charging indicators. The same reasoning can then be made for distance and time accessibility indicators when no route construction is used. Cost indicators need to define average transport costs but, since there are national road transport instances allowing to estimate those costs, the information is easy to retrieve (Gonzalez-Feliu, 2018). For route construction, a demand generation (in terms of freight quantity) is needed unless analytical models are used.

Freight generation needs to know the location and the characteristics of the different establishments of a city. Gravity and concentration indicators need both distance/ time/cost information and establishment location data. Those locations can be given in a geolocated way (allowing then to process and select information via GIS, and feed geospatial analytics tools) or in a zonal way (i.e., knowing the number of establishments by type with their mean characteristics and zone.) In all cases, GIS tools are required to process and prepare the indicator calculation, and not only for visualization purposes.

Finally, compatibility indicators remain more difficult to calculate, since they derive from route optimization, and need to define several characteristics and constraints related to urban deliveries (Cattaruzza et al., 2017). 
The computation of those accessibility and/or attractiveness indicators is then related to data needs. Those data can be geospatial (and, in all cases those data are required, GIS are mainly used to retrieve and prepare the geospatial information to estimate such indicators), socio-economic or functional (i.e., data constructs, models and estimations needed to prepare the data to finally compute the indicators). We report a summary of those data requirements in table 3.

\begin{tabular}{|c|c|c|c|c|}
\hline \multirow{2}{*}{ Type of indicators } & \multirow{2}{*}{ Indicators } & \multicolumn{2}{|c|}{ Types of primary data required } & \multirow{2}{*}{$\begin{array}{l}\text { Modeling and estimation } \\
\text { issues }\end{array}$} \\
\hline & & Spatial & Socio-economic & \\
\hline \multirow{4}{*}{$\begin{array}{l}\text { Infrastructure- } \\
\text { based, nodal }\end{array}$} & Logistics capacities & $\begin{array}{l}\text { Logistics facilities' location, } \\
\text { city zoning }\end{array}$ & $\begin{array}{l}\text { Logistics facilities' } \\
\text { characterization }\end{array}$ & - \\
\hline & Logistics service levels & $\begin{array}{l}\text { Logistics facilities' location, } \\
\text { city zoning }\end{array}$ & $\begin{array}{l}\text { Logistics facilities' } \\
\text { characterization }\end{array}$ & - \\
\hline & Parking capacities & $\begin{array}{l}\text { Delivery area/parking location } \\
\text { \& dimensions, city zoning }\end{array}$ & - & - \\
\hline & Parking service levels & $\begin{array}{l}\text { Delivery area/parking location } \\
\text { \& dimensions, city zoning }\end{array}$ & - & FTG rates \\
\hline \multirow{2}{*}{$\begin{array}{l}\text { Infrastructure- } \\
\text { based, edge }\end{array}$} & $\begin{array}{l}\text { Lane/road service } \\
\text { levels }\end{array}$ & $\begin{array}{l}\text { City network with an } \\
\text { infrastructure typology }\end{array}$ & - & $\begin{array}{c}\text { Database of network flow } \\
\text { charging }\end{array}$ \\
\hline & Speeds & $\begin{array}{l}\text { City network with an } \\
\text { infrastructure typology }\end{array}$ & - & $\begin{array}{c}\text { Database of speed travel in the } \\
\text { network }\end{array}$ \\
\hline \multirow{3}{*}{ Generation-based } & $\begin{array}{l}\text { Generation } \\
\text { Accessibility }\end{array}$ & City zoning & $\begin{array}{l}\text { Number of premises with } \\
\text { characteristics, per zone }\end{array}$ & FTG/FG modeling framework \\
\hline & Generation Density & $\begin{array}{l}\text { City zoning with area } \\
\text { estimation }\end{array}$ & $\begin{array}{l}\text { Number of premises with } \\
\text { characteristics, per zone }\end{array}$ & FTG/FG modeling framework \\
\hline & $\begin{array}{l}\text { Concentration } \\
\text { measures }\end{array}$ & $\begin{array}{c}\text { City zoning, inter-premise } \\
\text { distance }\end{array}$ & $\begin{array}{c}\text { Number of premises per } \\
\text { zone }\end{array}$ & $\begin{array}{c}\text { An assignment of each premise } \\
\text { to a zone is needed; } r \text { requires } \\
\text { to be defined }\end{array}$ \\
\hline \multirow[b]{2}{*}{$\begin{array}{l}\text { Distance, time } \\
\text { or cost }\end{array}$} & Direct indicators & $\begin{array}{c}\text { City zoning, distances between } \\
\text { zones }\end{array}$ & - & $\begin{array}{l}\text { Travel time, speed and/or } \\
\text { transport cost between zones }\end{array}$ \\
\hline & $\begin{array}{l}\text { Route-based } \\
\text { indicators }\end{array}$ & $\begin{array}{l}\text { Delivery customers' locations, } \\
\text { city zoning, distances between } \\
\text { locations }\end{array}$ & - & $\begin{array}{l}\text { A demand dataset is needed } \\
\text { for route construction, as well } \\
\text { as a vehicle routing algorithm } \\
\text { or analytic distance estimation } \\
\text { model; travel speeds and } \\
\text { unitary costs; service times }\end{array}$ \\
\hline \multicolumn{2}{|c|}{ Gravity-based } & $\begin{array}{c}\text { City zoning, distances between } \\
\text { locations }\end{array}$ & $\begin{array}{c}\text { Number of premises, } \\
\text { employment }\end{array}$ & $\begin{array}{l}\text { Travel times, unitary costs, } \\
\text { eventually FG models if freight } \\
\text { quantities are considered as } \\
\text { opportunities }\end{array}$ \\
\hline \multicolumn{2}{|c|}{ Space-time compatibility } & $\begin{array}{l}\text { Delivery customers' locations, } \\
\text { city zoning, distances between } \\
\text { locations }\end{array}$ & - & $\begin{array}{l}\text { A demand dataset (with } \\
\text { time constraints and service } \\
\text { times) is needed for route } \\
\text { construction, as well as a } \\
\text { vehicle routing algorithm }\end{array}$ \\
\hline
\end{tabular}


Table 3. Main data needed to estimate the proposed types of accessibility/attractiveness indicators. Those indicators, although primarily proposed by the research communities, have a direct use and application in real planning and management issues. Potential uses of those indicators from a territorial intelligence analytics viewpoint that respond to current requirements of practitioners are (the list is presented to illustrate the main applications of accessibility and attractiveness indicators in practice but does not aim to be exhaustive):

- Delivery area and/or parking design, dimensioning and planning (Dablanc and Beziat, 2015; Magniol et al., 2018). Nowadays, the definition of delivery areas is not matched with the needs in terms of demand, and the capacities (current or potential) are not always estimated systematically (CERTU, 2009). A nodal accessibility indicator would support decisions and assessments in that field, and help city planners and companies to reach a consensus on the strategy of delivery area planning in a city (Magniol et al., 2018).

- Retailing land use planning and store development (Desse, 2001; Hounwanou et al., 2018). Retailing accessibility (Gonzalez-Feliu and Mercier, 2013; GonzalezFeliu and Peris-Pla, 2018) may be used to define the needs in sustainable retailing planning, in order to propose land use plans which allow to decrease shopping trips by car and, at the same time, bring the basic food close to households to be accessible to the population. Moreover, mall and commercial center planning, construction and management need decision-support tools for both urban planners, who state in terms of retailing land use, and private construction and mall promotion companies, which aim to make their commercial center projects attractive to urban and periurban populations (Desse, 2002, 2014).

- Urban transport planning, urban land use planning or other territorial plan development, in which freight transport is starting to be included (CERTU-ADEME, 1998; Ballantyne et al., 2013). Since accessibility (mainly distance-time or gravity indicators) is used in transport and urban plans, the corresponding indicators for freight transport, their equivalent for freight, can give a double approach of accessibility, and feed the deployment of global assessments of the plans which would include both private and goods transport.

- Concentration indicators but in general freight generation attractiveness can also be used by real estate companies, wholesalers, industry and transport/logistics stakeholders for their location and market expansion strategies, based on freight transport potential which follows different patterns and determinants than those of household real estate (Kauko and d'Amato, 2009).

- Transport as a service, and more generally infomobility systems, would integrate spatial indicators, such as service levels (both nodal and edge), concentration or 
compatibility indicators, to support operational decisions of logistics carriers but also of private transport (mainly in the case of crowded transport or $c 2 c^{6}$ deliveries) to improve the sustainability of such trips (Gonzalez-Feliu et al., 2018).

- Although non-exhaustive, this list shows the potential of such indicators and of territorial intelligence analytics. However, since the proposed works generally deal with European and North American countries, it seems important to finish this paper by focusing on Latin America and its context, from the viewpoint of deploying such indicators in practice to see their potential but also the limits of their deployment.

\subsection{Territorial intelligence analytics and city logistics in Latin American cities}

We have previously seen that territorial intelligence analytics spatial indicators have a strong potential for city planners, real estate stakeholders, industrial and logistics managers, among others. However, since said indicators need various data sets coming from different sources, it is important to analyze the main data collection issues for Latin American cities. Indeed, the issue of data production related to urban planning and transport in Latin America is not new, and many authors presented the main issues regarding urban planning data production (Dale et al., 1992; Arraigada, 2003; Borja, 2003; Calderón and Sevén, 2004; Uchida and Nelson, 2009; Garrocho and Buzai, 2015) not focusing on urban freight transport. Moreover, according to Gonzalez-Feliu (2019), urban logistics is confronted with a data paradox: although big data and open data allow to produce a huge quantity and variety of information, that information is not always suitable or necessary to estimate the main data needed in urban logistics information systems (this is called by the author "the big-no data paradox"). This paradox is of great importance in Latin American cities for several reasons:

- From an urbanistic viewpoint, Latin American cities present city structures which combine modern headquarters with a strong land-planning organization and development, and popular headquarters which follow a road and public space land planning, with a heterogeneity of buildings and activity zones, and human settlements which obey to little or no planning issues (Metzger et al., 2015; Alexandri et al., 2016). Moreover, the capabilities of urban planning and the real actions performed in that field in Latin American cities are unequal in the different countries, and even within the same country (Cabeza, 2002).

- In Latin American cities, the levels of informal economies (Tokman, 1978; Friedmann, 2018), as well as the lack of unification in establishing company databases (Parra Herrera, 2017), make the availability of establishment files difficult, such as the standard national files of EU countries or USA states (Holguín-Veras et al., 2018). 
- Land-planning competencies are not standardized in many countries of the region, often resulting into an overlapping of competencies and actions of different public (and parapublic) actors (Palacios Argüello et al., 2016) who do not always communicate or exchange basic information (Castrellón-Torres et al., 2018).

- Last but not least, urban freight transport is often associated with private competencies in the countries of that region, and main priorities regarding traffic and urban planning are still given to private transport (as it was in other regions of the world until the beginning of the 21 st century). However, that vision is changing, and several Latin American countries are starting to deploy city-logistics planning actions and issues, most of them on a standard basis (Vieira et al., 2016; HolguínVeras et al., 2018).

Although those four issues are not the only specificities of Latin American cities, they strongly impact the current state of the art in urban logistics planning in that region, as well as the near-future actions (Gonzalez-Feliu and Cedillo-Campos, 2017). Moreover, data production issues are also strongly conditioned by a multistakeholder context, where collaboration is not always a habit (Parra Herrera, 2017; Rojas Huérfano et al., 2018). For those reasons, we propose a brief overview of the current state of the art in Latin American cities regarding data production for territorial intelligence analytics, and more specifically for accessibility indicators as presented in the previous section.

Concerning cartographic data, most Latin American metropolitan cities have nowadays GIS-based data which can be used for the construction of geospatial indicators (Parras and Ramírez, 2016). However, the availability of standard, national, geolocated databases of city areas, roads and built environments can differ in each country, although most of them have national geographic institutes producing various cartographic and spatial databases (Garrocho and Buzai, 2015). The road network geospatial information is not always updated and available. Anyway, a valid alternative is the use of OpenStreetMaps files, which are available at the corresponding website ${ }^{6}$ and propose basic geospatial information of most large and medium-sized Latin American cities. The main issues in Latin American cities concerning one of the most basic information needed to deploy spatial indicators are the heterogeneity of data production practices (national and/or local standards) and data availability, but it seems to be produced at least in a form and quality that allow to define most of the indicators proposed above.

Demographic and socio-economic data is more difficult to obtain, since the unreliability of economic activities, but also of some human settlements in urban

6 https://www.openstreetmap.org 
areas (Clichevsky, 2017; Soto, 2018), make it difficult to get an accurate census of both the population and economic activities. However, the statistics of the population of different urban areas (including informal settlements) is accurate and standard, since national statistics institutes have worked together to propose an extensive census of the population following a standard basis, at least within the country (Vignoli, 2002; Acosta, 2003). An economic census is also available. It includes only formal activities (Cevallos Vallejos, 2003; Santa María y Rozo, 2009) and misses an important part of the information, since informal economies account for $30-50 \%$ of the employees in Latin American cities (Portes and Haller, 2004; Chen, 2012). Moreover, an important part of the informal activities consists of non-sedentary activities, which are difficult to precisely geolocate, although they can be related to a zone of the city in which they operate. To deal with this lack, various assessment techniques can be performed (Portes and Haller, 2004) to estimate such activities, propose a global vision of the economic sectors of a city, and determine the indicators related to freight transport (Gonzalez-Calderon et al., 2018; Holguin-Veras et al., 2013). However, said estimations need to be aggregated at a zone level, with the geolocation being not possible to be given in such context. Anyway, the main demographic and socio-economic information seems to be able to be reproduced and determined to propose suitable accessibility indicators.

Regarding transport flow data, Latin American cities still lack standard surveys in that field. For example, in Lima, two private transport surveys promoted by the Japan International Cooperation Agency (JICA) were carried out for years 2003 and 2014. Those surveys fed the Master Plan for Lima and Callao Metropolitan Area Urban Transportation (Yachiyo Engineering Co. Ltd. and Pacific Consultants International, 2005), and presented the definition of Origin-Destination Matrix. Although those surveys address private transport, several commercial trips, and more importantly shopping trips, are reported. This allows to define trip flows but also centrality and attractiveness of zones for logistics and retailing/shopping purposes. Another alternatives to transport surveys are traffic counts and cordon surveys, which are more common in the cities of the region ${ }^{7}$ (Christopher, 1995; Shifter et al., 2005; Saide et al., 2009; Quintero et al., 2010; GonzalezCalderon et al., 2018).

Concerning freight, most Latin American cities did not deploy (at least yet and to the best of our knowledge) a standard survey, such as the surveys carried out with the FTG methodology in more than 20 countries (Holguín-Veras, 2016). Only Medellín (Gonzalez-Calderon et al., 2018) has presented a survey which encompasses the whole city. Bogotá has also presented partial FTG surveys, focused on industrial, wholesaling or retailing zones (Parra Herrera, 2017), for which approximated FTG models can be

7 Traffic counts are mainly used in Latin America for vehicle inventorying and traffic pollution impact estimation. 
deployed. Similarly, in the context of night delivery programs (Holguin-Veras et al., 2018), surveys are being performed in various Latin American cities (like São Paulo or Bogotá, among others) using a standard questionnaire, which can deploy FTG models based on the models of Holguin-Veras et al. (2013).

However, various data collection procedures have been carried out in Latin American cities, mainly in the context of the $\mathrm{km}^{2}$ methodology (Regal, 2018; Suarez-Nunez and Gonzalez-Feliu, 2018). Those surveys, which cover small zones (of about $1 \mathrm{~km}^{2}$ of surface) and just few zones (in general 3 to 5 zones in each city), are aimed to characterize high freight generators, and not to develop FG or FTG models generalizable to a city. However, when coupled with an establishment survey, and for surveyed activities, such data collection allows to gather enough information to estimate FTG rates and generalize them to all the establishments of the same type in the city. Another option is to use carrier data to produce the necessary information to characterize supply chains (Padilla Solís, 2016), focusing on urban deliveries (Gonzalez-Feliu, 2019).

As shown above, it seems that data is not a main limiting issue, although it needs to be produced in a suitable way to deploy relevant indicators. In the deployment of such indicators, it is important to consider the main goals, the main users, the context of application, and the needs of aggregation and data quality to produce a representative indicator (in the sense of problem-solving, Ackoff, 1977; Gonzalez-Feliu, 2019).

\section{Conclusions}

This paper presented an overview of spatial accessibility and attractiveness indicators for urban freight transport and logistics in the context of business intelligence and analytics, as well as the main practical implications for its deployment in Latin American cities in planning and development issues, including urban logistics and freight transport. Moreover, it introduced a definition of territorial intelligence and analytics from its analogous notion in business, as well as a brief overview of the main categories of indicators. Then, it focused on the definition of indicators to account for two reciprocal notions: accessibility and attractiveness. A typology of five categories of indicators has been proposed and overviewed, showing the state of the art and the main calculation issues. Finally, data and context application issues are proposed, first from a general viewpoint and then from the perspective of their deployment in Latin American cities' planning and management.

The various categories of indicators need different data and account for slightly different aspects of accessibility and attractiveness. They are adapted to different uses, such as retail development, infrastructure dimensioning and planning, or parking and access issues, among others. As shown in the paper, such issues do not only involve city planners but also logistics managers and carrier stakeholders. Moreover, data issues, which are seen 
in Latin America as a limitation to the deployment of analytics-based approaches, are to be examined to produce the most suitable indicators with the data available for the requested uses. In other words, territorial intelligence accessibility indicators may be a first approach to define socio-economic issues, such as inequalities, food and goods accessibilities, logistics needs and vulnerabilities, or deficiencies in logistics levels of service, among others, which can synergically be performed using existing data, in order to provide a first easy-to-assess and easy-to-understand decision-support tool. Moreover, since the data used to define such indicators exists and is available, and may be standardized for the entire region (or the indicators being proposed may be standardized worldwide), it can be a good dialogue and communication tool among urban stakeholders (public and private) to reach a consensus on the priority zones, in terms of logistics and the main actions that may be carried out.

Finally, we aim to address four main directions that research would follow to develop and improve such indicators. The first one is related to data processing and production methods to provide standards and unified methodologies, so that the use of such indicators becomes a habit as already is in private transport. The second one is to go in-depth into the links between socio-spatial patterns (defined by accessibility and attractiveness indicators) and logistics flow intensity and characteristics, to formalize the links between logistics and territorial development. The third one consists in defining territorial intelligence and analytics spatial dashboards, based on a sustainable development, and then focusing on the spatial-visual representation of such indicators (not only on accessibility and attractiveness but combining them with socio-economic and environmental indicators to produce sustainable spatial dashboards). Finally, the last one involves the evolution of current indicators to define Key Spatial Indicators (KSI) that seem to be the next step of Territorial Intelligence and Analytics.

\section{References}

Abril, M., Barber, F., Ingolotti, L., Salido, M. A., Tormos, P., y Lova, A. (2008). An assessment of railway capacity. Transportation Research Part E: Logistics and Transportation Review, 44(5), 774-806.

Ackoff, R. L. (1977). Optimization+objectivity=optout. European Journal of Operational Research, 1(1), 1-7.

Acosta, F. (2003). La familia en los estudios de población en América Latina: estado del conocimiento y necesidades de investigación. Papeles de población, 9(37), 9-50.

Alexandri, G., González, S., y Hodkinson, S. (2016). Geografías del desplazamiento en el urbanismo de América Latina. Revista INVI, 31(88), 9-25.

Amico, S. (2005), Introduzione di finestre temporali in algoritmi per la distribuzione delle merci: metodologia e analisi degli effetti. Master Thesis, Politecnico di Torino, Turin, Italy. 
Andriankaja, D., Gondran, N., y Gonzalez-Feliu, J. (2015). Assessing the environmental impacts of different IPSS deployment scenarios for the light commercial vehicle industry. Procedia CIRP, 30, 281-286.

Antoni, J. P. (2016). Concepts, méthodes et modèles pour l'aménagement et les mobilités: l'aide à la décision face à la transition éco-énergétique. Economica, Paris.

Avelar-Sosa, L., García-Alcaraz, J. L., Cedillo-Campos, M. G., y Adarme-Jaimes, W. (2014). Effects of regional infrastructure and offered services in the supply chains performance: Case Ciudad Juarez. Dyna, 81(186), 208-217.

Ballantyne, E. E., Lindholm, M., y Whiteing, A. (2013). A comparative study of urban freight transport planning: addressing stakeholder needs. Journal of transport geography, 32, 93-101.

Barbero, J. A. (2010). Freight logistics in Latin America and the Caribbean: An agenda to improve performance. Inter-American Development Bank.

Barles, S. (2018). L'aménagement et l'urbanisme: disciplines de l'interface, interdisciplines. Revue européenne des sciences sociales, 56(1), 203-218.

Barrientos, A. H., Morales, A. E. V., y González, T. V. (2018). Mexican Rural Communities' Metabolism and Its Impact on Socioeconomic Indicators. In April, W. (Ed.) Culture and identity (pp. 41-56). Intechopen.

Ben-Akiva, M., y Lerman, S. R. (1979). Disaggregate travel and mobility choice models and measures of accessibility. Behavioural travel modelling, 654-679.

Bertacchini, Y. (2004). Entre information y processus de communication: l'intelligence territoriale. Les Cahiers du Centre d'études et de Recherche, Humanisme et Entreprise $n^{\circ}$ 267. La Sorbonne Nouvelle, Paris.

Betanzo-Quezada, E., y Romero, J. A. (2010). An urban freight transport index. Procedia-Social and Behavioral Sciences, 2(3), 6312-6322.

Béziat, A. (2017). Approche des liens entre transport de marchandises en ville, formes urbaines et congestion: Le cas de I'lle-de-France (Doctoral dissertation, Université Paris-Est).

Blanco, E. (2014). Urban Logistics: a Latin American Perspective. Corporación Andina de Fomento.

Borja, J. (2003). Ciudad y planificación: la urbanística para las ciudades de América Latina. Cuadernos de la CEPAL.

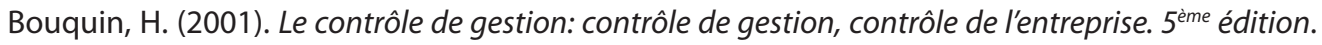
Presses Universitaires de France, Paris

Bowen, J. T. (2008). Moving places: the geography of warehousing in the US. Journal of Transport Geography, 16(6), 379-387.

Bozzo, R., Conca, A., y Marangon, F. (2014). Decision support system for city logistics: literature review, and guidelines for an ex-ante model. Transportation Research Procedia, 3, 518-527. 
Cabeza, Á. M. (2002). Ordenación del territorio en América Latina. Scripta Nova Revista Electrónica de Geografía y Ciencias Sociales, 6(125), 1.

Cai, X.L., y Chen C.Y. (2004). The Prediction and Analyse of Regional Logistics Demand [J]. Logistics Management, 12, 004.

Calderón, C., y Servén, L. (2004). Trends in infrastructure in Latin America, 1980-2001. The World Bank.

Castrellón-Torres, J. P., Chaparro, J. S. T., Barrera, N. E. M., Acosta, J. H. T., y Jaimes, W. A. (2018). Information Technology in City Logistics: A Decision Support System for Off-Hour Delivery Programs. In Exploring Intelligent Decision Support Systems (pp. 221-238). Springer, Cham.

Cattaruzza, D., Absi, N., Feillet, D., y González-Feliu, J. (2017). Vehicle routing problems for city logistics. EURO Journal on Transportation and Logistics, 6(1), 51-79.

Cedillo-Campos, G. (2015). Supply chain performance measurement in Latin America. Report for the International Transportation Forum and National Research Council of Mexico, Querétaro.

CERTU (2009). Aménagement des aires de livraison. Guide pour leur quantification, leur localisation et leur dimensionnement. CERTU, Lyon.

CERTU-ADEME (1998). Plans de déplacement urbain. Prise en compte des marchandises. CERTU, Lyon.

Chen, H., Chiang, R. H., y Storey, V. C. (2012). Business intelligence and analytics: from big data to big impact. MIS quarterly, 1165-1188.

Chen, M. A. (2012). La economía informal: definiciones, teorías y políticas. Mujeres en Empleo Informal: Globalizando y Organizando (WIEGO), London.

Chiabaut, N., Sigaud, J. M., Marques, G., y Gonzalez-Feliu, J. (2015). Impacts of urban logistics on traffic flow dynamics. In Lauras, M., Zelm, M., Archimède, B., Bénaben, F., y Doumeignts, G. (Eds.) Enterprise Interoperability: I-ESA 14 (pp. 181-187). John Wiley \& Sons.

Chiabaut, N., Lopez, C., y Leclercq, L. (2016). Evaluation of the performance of an Urban freight system using a multi-use-lane arterial. In Proceedings of the Meeting of the Transportation Research Board.

Chiasson, G., Girardot, J. J., Charlebois, Y., y Bensouda, R., Eds. (2014). Proceedings of the $1^{\text {st }}$ Intercontinental Conference of Territorial Intelligence; "ICI Territories: Intelligence, Communication and Territorial Engineering to Think Together the Sustainable Development of the Territories", Gatineau, Canada, October. INTI, Besançon.

Chicaiza-Vaca, J., y Hidalgo-Carvajal, D. (2018). Characterization of urban logistics in an HORECA intensive area. Case study: "TheT Zone"in Bogotá, Colombia. In Supply Chain Management and Logistics in Latin America: A Multi-Country Perspective. Emerald Publishing, Bingley.

Christopher, P. (1995) Transportation Modeling for Energy and Environment: US Experience and Relevance to the Developing World. Transportation Research Record, 1487, 41-48. 
Clichevsky, N. (2017). Hábitat informal en América Latina: entre la permisividad, el desalojo y la regularización. Territorios, (6), 15-30.

Coba, L., Pérez Franco, R., Gonzalez-Feliu, J., y Chong, M. (2018, July). Improved planning of the demand of imported corn seeds in Hortus SC. In 7th International Conference on Information Systems, Logistics and Supply Chain, ILS 2018 (pp. 367-374).

Combes, F. (2016). A theoretical analysis of the cost structure of urban logistics. Proceedings of the 6th International Conference in Informations Systems, Logistics and Supply Chain, Bordeaux, France, June 1-4, 2016, Kedge Business School, Bordeaux, ISBN 978-2-9539787-3-5.

Comi, A., Buttarazzi, B., Schiraldi, M. M., Innarella, R., Varisco, M., y Rosati, L. (2017). DynaLOAD: a simulation framework for planning, managing and controlling urban delivery bays. Transportation research procedia, 22, 335-344.

Cooper, A. (2012). What is analytics? Definition and essential characteristics. CETIS Analytics Series, 1(5), 1-10.

Crainic, T. G., Perboli, G., Mancini, S., y Tadei, R. (2010). Two-echelon vehicle routing problem: a satellite location analysis. Procedia-Social and Behavioral Sciences, 2(3), 5944-5955.

Crozet, Y., Mercier, A., y Ovtracht, N. (2012). 15. Accessibility: a key indicator to assess the past and future of urban mobility. In Geurs, K.T., Krizek, K., J., Reggiani, A. (Eds.) Accessibility analysis and transport planning: Challenges for Europe and North America, (pp. 263-279). Edward Elgar Publishing Limited.

Dablanc, L. (2011). City distribution, a key element of the urban economy: guidelines for practitioners. In Macharis, C., y Melo, S. (Eds.) City distribution and urban freight transport: multiple perspectives (pp. 13-36), Edward Elgar.

Dablanc, L., y Rodrigue, J. P. (2014). Urban freight distribution: a global typology. In Giuliano, G., y Hanson, S. (Eds.) The Geography of Urban Transportation, 4th Edition (pp. 34-56). The Guilfold Press, New York.

Dablanc, L., y Beziat, A. (2015). Parking for freight vehicles in dense urban centers-The issue of delivery areas in Paris. In 94th Annual Meeting of the Transportation Research Board, Washington, DC.

Daganzo, C. F. (2005). Logistics systems analysis. Springer Science \& Business Media.

Dale, V. H., Southworth, F., O'Neill, R. V., y Rosen, A. (1992). Simulating spatial patterns of land-use change in Rondônia, Brazil (No. CONF-9108232--1). Oak Ridge National Lab.

De Kort, A. F., Heidergott, B., y Ayhan, H. (2003). A probabilistic (max, +) approach for determining railway infrastructure capacity. European Journal of Operational Research, 148(3), 644661.

De la Barra, T., Franco, H., y Ramos, R. (2012). El Modelo de Chile: Insumo-Producto y Asignación Multimodal de Carga y Pasajeros. Ingeniería de Transporte, 16(2).

Deflorio, F. P., Gonzalez-Feliu, J., Perboli, G., y Tadei, R. (2012). The influence of time windows on the costs of urban freight distribution services in city logistics applications. European Journal of Transport and Infrastructure Research, 12(3), 256-274. 
Desse, R. P. (2001). Le nouveau commerce urbain. Dynamiques spatiales et stratégies des acteurs. Presses universitaires de Rennes.

Desse, R. P. (2002). Les centres commerciaux français, futurs pôles de loisirs? Flux, 4, 6-19.

Desse, R. P. (2014). Quelle résilience pour les espaces commerciaux? Le cas français. GOT, Revista de Geografia e Ordenamento do Território, (6), 45-69.

Dima, C. (2016). New Approaches of Investment Management Used in Context of Territorial Intelligence. Business Excellence and Management, 6(4), 36-44.

Dodman, D. (2009). Blaming cities for climate change? An analysis of urban greenhouse gas emissions inventories. Environment and urbanization, 21(1), 185-201.

Ducret, R., y Gonzalez-Feliu, J. (2016). Connecting demand estimation and spatial category models for urban freight: First attempt and research implications. Transportation research procedia, 12, 142-156.

Dumas, P., Gardère, J. P., y Bertacchini, Y. (2007). Contribution of socio-technical systems theory concepts to a framework of Territorial Intelligence. In Huelva Caenti Conference (pp. 1-13).

Duranton, G., y Overman, H. G. (2005). Testing for localization using micro-geographic data. The Review of Economic Studies, 72(4), 1077-1106.

Fischetti, M., Lodi, A., Martello, S., y Toth, P. (2001). A polyhedral approach to simplified crew scheduling and vehicle scheduling problems. Management Science, 47(6), 833-850.

Fontes Lima Jr, O., Rutkowski, E. W., De Carvalho, C. C., y Lima, J. C. F. (2010). Sustainable logistics platform in a regional Brazilian airport. WIT Transactions on State of the Art in Science and Engineering, Vol 48, 87-98.

Fransoo, J. C., Blanco, E. E., y Mejía Argueta, C. M. (2017). Reaching 50 million nanostores: retail distribution in emerging megacities. CreateSpace Independent Publishing Platform.

Friedmann, J. (2018). The barrio economy and collective self-empowerment in Latin America. In Life Space and Economic Space (pp. 120-156). Routledge.

Garrocho, C., y Buzai, G. D. (Eds.). (2015). Geografía aplicada en Iberoamérica: avances, retos y perspectivas. El Colegio Mexiquense.

Geurs, K. T., y Van Wee, B. (2004). Accessibility evaluation of land-use and transport strategies: review and research directions. Journal of Transport geography, 12(2), 127-140.

Girardot J.J. (2000). Principes, Méthodes et Outils d 'Intelligence Territoriale. Évaluation participative et Observation coopérative. In Conhecer melhor para agir melhor (pp. 7-17). DGAS, Lisbon.

Girardot, J. J. (2009). Evolution of the concept of territorial intelligence within the coordination action of the European network of territorial intelligence. Res-Ricerca e Sviluppo per le politiche sociali, Nuova serie, 1-2, 11-29.

Giuliano, G., Gordon, P., Pan, Q., y Park, J. (2010). Accessibility and residential land values: some tests with new measures. Urban Studies, 47(14), 3103-3130. 
Giuliano, G., Kang, S., y Yuan, Q. (2016). Spatial dynamics of the logistics industry and implications for freight flows. Final Report. Project No. NCST-20160600.

Gonzales, R., Wareham, J., y Serida, J. (2015). Measuring the Impact of Data Warehouse and Business Intelligence on Enterprise Performance in Peru: A Developing Country. Journal of Global Information Technology Management, 18(3), 162-187.

Gonzalez-Calderon, C. A., Sánchez-Díaz, I., Sarmiento-Ordosgoitia, I., y Holguín-Veras, J. (2018). Characterization and analysis of metropolitan freight patterns in Medellin, Colombia. European Transport Research Review, 10(2), paper n²3, 1-11.

Gonzalez-Feliu, J. (2008a). Models and methods for city logistics planning and management. LET Seminar, Lyon, 4 June 2008.

Gonzalez-Feliu, J. (2008b). Models and methods for the city logistics: The two-echelon capacitated vehicle routing problem (Doctoral dissertation, Politecnico di Torino).

Gonzalez-Feliu, J. (2011). Two-echelon transportation optimisation: unifying concepts via a systematic review. Working Papers on Operations Management, 2(1),18-30.

Gonzalez-Feliu, J. (2012). Freight distribution systems with cross docking: A multidisciplinary analysis. Journal of the Transportation Research Forum, 51(1), 143-149.

Gonzalez-Feliu, J. (2013). Vehicle Routing in Multi-Echelon Distribution Systems with CrossDocking: A Systematic Lexical-Metanarrative Analysis. Computer and Information Science, 6(3), 28-47.

Gonzalez-Feliu, J. (2018). Sustainable Urban Logistics: Planning and Evaluation. John Wiley \& Sons.

Gonzalez-Feliu, J. (2019). Logistics and Transport Modeling in Urban Goods Movement. IGI Global, Hershey.

Gonzalez-Feliu, J., y Mercier, A. (2013). A double people-freight accessibility approach for urban retailing and leissure planning at strategic level. $5^{\text {th }}$ METRANS International Conference on Urban Freight, Long Beach, California, October $6^{\text {th }}-8^{\text {th }}$.

Gonzalez-Feliu, J., Basck, P., y Morganti, E. (2013a). Urban logistics solutions and financing mechanisms: a scenario assessment analysis. European Transport/Trasporti Europei, 54(11), 1-16.

Gonzalez-Feliu, J., Pluvinet, P., Serouge, M., y Gardrat, M. (2013b). Urban Freight Analysis Based on GPS Data. In Hsuesh, Y.H. (ed.), Global Positioning Systems: Signal Structure, Applications and Sources of Error and Biases, Nova Science Publishers, New York, pp. 73-93.

Gonzalez-Feliu, J., y Morana, J. (2014). Assessing urban logistics pooling sustainability via a hierarchic dashboard from a group decision perspective. In Macharis, C., Melo, S., Woxenius, J., y Van Lier, T. (Eds.) Sustainable Logistics (pp. 113-135). Emerald Group Publishing Limited.

Gonzalez-Feliu, J., y Salanova Grau, J. M. (2014). How the location of urban consolidation and logistics facility has an impact on the delivery costs? An accessibility analysis. In Transport Research Arena Conference 2014. 
Gonzalez-Feliu, J., Malhéné, N., Morganti, E., y Morana, J. (2014a). The deployment of city and area distribution centers in France and Italy: Comparison of six representative models. Supply chain forum: An international journal, 15(4), 84-99.

Gonzalez-Feliu, J., Salanova Grau, J. M., y Beziat, A. (2014b). A location-based accessibility analysis to estimate the suitability of urban consolidation facilities. International Journal of Urban Sciences, 18(2), 166-185.

Gonzalez-Feliu, J., Taniguchi, E., y d'Arcier, B. F. (2014c). Financing urban logistics projects. In Gonzalez-Feliu, J., Semet, F., y Routhier, J.L. (Eds.) Sustainable Urban Logistics: Concepts, Methods and Information Systems (pp. 245-265). Springer, Berlin, Heidelberg.

Gonzalez-Feliu, J., Muñuzuri, J., Cedillo-Campos, M. G., Ambrosini, C., Taniguchi, E., y Chiabaut, N. (2015). Restrictions d'accès au centre-ville: à la recherche du «véhicule optimal» urbain. Logistique \& Management, 23(2), 31-44.

Gonzalez-Feliu, J., y Battaia, G. (2017). La mutualisation des livraisons urbaines: quels impacts sur les coûts et la congestion? Logistique \& Management, 25(2), 107-118.

González-Feliu, J., y Cedillo-Campos, M. G. (2017). Presentación. Logística y desarrollo territorial. Revista Transporte y Territorio, 17, 1-9.

Gonzalez-Feliu, J., y Peris-Pla, C. (2017). Impacts of retailing attractiveness on freight and shopping trip attraction rates. Research in Transportation Business \& Management, 24, 49-58.

Gonzalez-Feliu, J., y Sánchez-Díaz, I. (2018a). The influence of aggregation level and category construction on estimation quality for freight trip generation models. Transportation Research Part E: Logistics and Transportation Review.

Gonzalez-Feliu, J., Palacios-Argüello, L. V., y Suárez-Núñez, C. (2018b). The relations between freight trip generation and gravity accessibility: An exploratory analysis. In Logistics Operations Management (GOL), 2018 4th International Conference on (pp. 1-6). IEEE.

Gonzalez-Feliu, J., Pronello, C., Salanova Grau, J. M. (2019). Multi-stakeholder collaboration in urban transport: state-of-the-art, contribution of the present issue and research opportunities. Transport, in press.

Guzmán-Jiménez, R. M., Barreno-Vereau, E., y. Medina-Merino, R. F. (2016). Sistema de información de emisiones de $\mathrm{CO}_{2}$. Interfases, 9, 117-147.

Hägerstrand, T. (1970), What About People in Regional Science? Papers of the Regional Science Association, 24, 7-21.

Hansen, W.G. (1959). How accessibility shapes land use. Journal of the American Institute Planners, 25, 73-76.

Hegron, G., y Haxaire, O., eds. (2012). Modélisation urbaine: de la représentation au projet. Ministère de I'Ecologie, du Développement Durable et de I'Energie, Direction de la Recherche et de I'Innovation, La Défense, France.

Helling, A. (1998). Changing intra-metropolitan accessibility in the US: Evidence from Atlanta. Progress in Planning, 49(2), iii-107. 
Holguin-Veras, J. (2016). Applications of Data from Establishment Surveys. Third VREF conference on urban freight: Plan for the future - sharing urban space. $17^{\text {th }}-19^{\text {th }}$ October, Gothenburg, Sweden.

Holguín-Veras, J., Encarnación, T., González-Calderón, C. A., Winebrake, J., Wang, C., Kyle, S., Herazo-Padilla, N., Kalahasthi, L., Adarme, J., Cantillo, V., Yoshizaki, H., y Garrido, R. (2018). Direct impacts of off-hour deliveries on urban freight emissions. Transportation Research Part D: Transport and Environment, 61(A), 84-103.

Holguín-Veras, J., Ramírez-Ríos, D.G., Encarnación, T., González-Feliu, J. Caspersen, E., RiveraGonzález, C., González-Calderón, C.A., y da Silva Lima, R. (2018) Metropolitan Economies and the Generation of Freight and Service Activity: An International Perspective. In Browne, M., Behrends, S., Holguín-Veras, J., Giuliano, G., y Woxenius, J. (eds.) Urban Logistics. Management, Policy and Innovation in a Rapidly Changing Environment (pp. 1951). Kogan Page, London.

Holguín-Veras, J., Sánchez-Díaz, I., Lawson, C. T., Jaller, M., Campbell, S., Levinson, H. S., y Shin, H. S. (2013). Transferability of freight trip generation models. Transportation Research Record, 2379(1), 1-8.

Holsapple, C., Lee-Post, A., y Pakath, R. (2014). A unified foundation for business analytics. Decision Support Systems, 64, 130-141.

Hounwanou, S., Comi, A., Gonzalez-Feliu, J., y Gondran, N. (2018). Inner city versus urban periphery retailing: store relocation and shopping trip behaviours. Indications from Saint-Etienne. Transportation research procedia, 30, 363-372.

Ingram, D. R. (1971). The concept of accessibility: a search for an operational form. Regional Studies, 5, 101-107.

Kauko, T., y d'Amato, M. (Eds.). (2009). Mass appraisal methods: An international perspective for property valuers. John Wiley \& Sons.

Kerzner, H. (2017). Project management metrics, KPIs, and dashboards: a guide to measuring and monitoring project performance. John Wiley \& Sons.

Kourtit, K., y Nijkamp, P. (2018). Big data dashboards as smart decision support tools for i-citiesAn experiment on stockholm. Land use policy, 71, 24-35.

Lama More, C. (2010). Gamarra: Logística inteligente para una ciudad mejor. En Vía, 2010 (4), 14-15.

Laroche, F. (2014). Economie politique des infrastructures ferroviaires (Doctoral dissertation, Université Lumière-Lyon II).

Laursen, G. H., y Thorlund, J. (2016). Business analytics for managers: Taking business intelligence beyond reporting. John Wiley \& Sons.

Lawson, C., Holguín-Veras, J., Sánchez-Díaz, I., Jaller, M., Campbell, S., y Powers, E. (2012). Estimated generation of freight trips based on land use. Transportation Research Record: Journal of the Transportation Research Board, 2269, 65-72. 
Lendjel, E., y Fischman, M. (2014, January). Innovations in Barge Transport for Supplying French Urban Dense Areas: A Transaction Costs Approach. Supply Chain Forum: An International Journal, 15(4), 16-27.

Liu, X., y Ma, S. (2005, October). Quantitative analysis of enterprise's logistics capability based on supply chain performance. In e-Business Engineering, 2005. ICEBE 2005. IEEE International Conference on (pp. 191-194). IEEE.

Lopez, C. (2017). Modélisation dynamique du trafic et transport de marchandises en ville: vers une approche combinée (Doctoral dissertation, Université de Lyon).

Macário, R., Rodrigues, M., Gama, A., Timms, P., Lama, C., Amaral, M., Schoemaker, J.; Tromp, N., Quinn, D., Abranches, G. (2011). Handbook on Urban Logistics - TURBLOG_ww: Transferability of urban logistics concepts and practices from a worldwide perspective. TIS.pt - Transportes, Inovação e Sistemas, S.A., Lisbon.

Magniol, S., Lopez, C., Gonzalez-Feliu, J., Chiabaut, N., Leclercq, L. (2018), The searching time to measure the Freight Loading Zone Accessibility using microscopic traffic simulation. In Proceedings of the $7^{\text {th }}$ International Conference on Information Systems, Logistics and Supply Chain, ILS 2018, Lyon, 8-11 July, pp. 406-414.

Marcon, E., y Puech, F. (2003). Evaluating the geographic concentration of industries using distance-based methods. Journal of Economic Geography, 3(4), 409-428.

Marcon, E., y Puech, F. (2009). Measures of the geographic concentration of industries: improving distance-based methods. Journal of Economic Geography, 10(5), 745-762.

Martínez, F.J. (1995). Access: the transport-land use economic link. Transportation Research Part $B, 29(6), 457-470$.

Masson, S., y Petiot, R. (2012). Attractivité territoriale, infrastructures logistiques et développement durable. Les Cahiers Scientifiques du transport, 61, 63-90.

Melo, S., y Costa, A. (2011). Definition of a set of indicators to evaluate the performance of urban goods distribution initiatives. In Macharis, C., y Melo, S. (eds.), City Distribution and Urban Freight Transport: Multiple Perspectives (pp. 120-149). Edward Elgar, Northampton.

Merchán Dueñas, D. E. (2015). Transshipment networks for last-mile delivery in congested urban areas. Master thesis, Massachusetts Institute of Technology).

Metzger, P., Gluski, P., Robert, J., y Sierra, A. (2015). Atlas problemático de una metrópoli vulnerable: desigualdades urbanas en Lima et Callao. Institut Français d'Etudes Andines, Coll. Travaux de I'Institut Français d'Etudes Andines, vol. 331, Lima.

Montoya-Torres, J. R., Muñoz-Villamizar, A., y Vega-Mejía, C. A. (2016). On the impact of collaborative strategies for goods delivery in city logistics. Production Planning \& Control, 27(6), 443-455.

Muller, M. L. (2007). Competitive intelligence in business: Latin America. South African Journal of Information Management, 9(2), paper a19, online: https://sajim.co.za/index.php/SAJIM/ article/viewFile/19/19. 
Muñuzuri, J., Grosso, R., Cortés, P., y Guadix, J. (2013). Estimating the extra costs imposed on delivery vehicles using access time windows in a city. Computers, Environment and Urban Systems, 41, 262-275.

Negash, S., y Gray, P. (2008). Business intelligence. In Handbook on decision support systems 2 (pp. 175-193). Springer, Berlin, Heidelberg.

Norman, J., MacLean, H. L., y Kennedy, C. A. (2006). Comparing high and low residential density: life-cycle analysis of energy use and greenhouse gas emissions. Journal of urban planning and development, 132(1), 10-21.

Padilla Solís, J. A. (2014). La evolución del planeamiento de ventas y operaciones. Interfases, 7, 105-116.

Padilla, J. (2006). Cerrando brechas entre el marketing y las tecnologías de información. Interfases, $1,79-89$.

Padilla-Solís, J. A. (2016). Inserción de las empresas peruanas en las cadenas globales de suministro. In Metas del Perú al Bicentenario, 1 ra edición (pp. 232-248). Consorcio de Universidades, Lima.

Palacios Argüello, L., Parra Herrera, J. E., y Adarme Jaimes, W. (2016). Data requirements for urban logistics decision support: Case of loading and unloading operations in Bogotá, Colombia. In 6th International Conference on Information Systems, Logistics and Supply Chain, ILS 2016.

Parra Herrera, J. E. (2017). Estrategias de coordinación en operaciones de cargue y descargue de mercancías. Master Thesis. Universidad Nacional de Colombia-Sede Bogotá.

Parra Herrera, J. E., Palacios Argüello, L. V., Gonzalez-Feliu, J., y Adarme Jaimes, W. (2017). Decision Support System Design Requirements, Information Management, and Urban Logistics Efficiency: Case Study of Bogotá, Colombia. In Handbook of Research on Information Management for Effective Logistics and Supply Chains (pp. 223-238). IGI Global.

Parras, M. A., y Ramírez, M. L. (2016). Propuesta metodológica para el modelado de la demanda potencial del transporte público mediante el empleo de sistemas de información geográfica. Revista Transporte y Territorio, 14, 109-121.

Patier, D., David, B., Chalon, R., y Deslandres, V. (2014). A new concept for urban logistics delivery area booking. Procedia-Social and Behavioral Sciences, 125, 99-110.

Pavone, G. (1997). Eléments d'évaluation de la qualité du service de transport ferroviaire. Rail international, 28(6), 47-59.

Pirie, G.H. (1979). Measuring accessibility: a review and proposal. Environment and Planning A, 11, pp. 299-312.

Pluvinet, P., Gonzalez-Feliu, J., y Ambrosini, C. (2012). GPS data analysis for understanding urban goods movement, Procedia - Social and Behavioral Science, vol. 39, pp. 450-462.

Portes, A., y Haller, W. J. (2004). La economía informal. Cepal. 
Quak, H. J., y de Koster, M. R. B. (2009). Delivering goods in urban areas: how to deal with urban policy restrictions and the environment. Transportation science, 43(2), 211-227.

Quintero, Á., Angulo, C., y Guerrero, J. (2010). Determinación de tasas de generación de viajes para conjuntos residenciales ubicados en la ciudad de Mérida, Venezuela. Ciencia e Ingeniería, 32(1), 45-54.

Rafele, C. (2004). Logistic service measurement: a reference framework. Journal of Manufacturing Technology Management, 15(3), 280-290.

Recker, W.W., Chen, C. y McNally, M.G. (2001). Measuring the impact of efficient household travel decisions on potential travel time savings and accessibility gains. Transportation Research A, 35(4), 339-369.

Regal, A. (2018). An Expansion on the KM2 Methodology: A Clustering Algorithm Comparison for the Case of Li. In 2018 MIT SCALE Latin America Conference.

Ripley, B. D. (1977). Modelling spatial patterns. Journal of the Royal Statistical Society. Series $B$ (Methodological), 172-212.

Rodrigue, J. P. (2004). Freight, gateways and mega-urban regions: the logistical integration of the Bostwash corridor. Tijdschrift voor economische en sociale geografie, 95(2), 147-161.

Rodrigue, J. P., y Notteboom, T. (2010). Comparative North American and European gateway logistics: the regionalism of freight distribution. Journal of Transport Geography, 18(4), 497-507.

Rojas Huérfano, L. F., Castrellón Torres, J. P., y Adarme Jaimes, W. (2018). Políticas públicas en logística urbana. Construcción colectiva de lineamientos para la logística de BogotáColombia. Ingeniería, Investigación y tecnología, 19(2), 159-169.

Saide, P., Zah, R., Osses, M., y de Eicker, M. O. (2009). Spatial disaggregation of traffic emission inventories in large cities using simplified top-down methods. Atmospheric Environment, 43(32), 4914-4923.

Sánchez Vegas, S. (2004). Knowledge Management: intellectual capital and social capital. An approach for Latin America. IFLA journal, 30(2), 156-165.

Sanchez-Diaz, I., Holguín-Veras, J., y Wang, C. (2013). Assessing the role of land-use, network characteristics, and spatial effects on freight trip attraction. Transportation Research Board 92nd Annual Meeting. Washington DC.

Santa María, M., y Rozo, S. (2009). Análisis cualitativo y cuantitativo de la informalidad empresarial en Colombia. Desarrollo y Sociedad, (63).

Ségalou E., Ambrosini, C., y Routhier, J.L. (2004). The environmental assessment of urban goods movement. In Taniguchi, E., and Thomson, R. G. (eds.). Logistics Systems for Sustainable Cities. Elsevier, Amsterdam, pp. 207-220.

Soto, A. L. R. (2018). El papel del sector informal en dos economías de América Latina: México y Guatemala. RICEA Revista Iberoamericana de Contaduría, Economía y Administración, 7(14), 82-106. 
Stewart, J. Q. (1947). Empirical mathematical rules concerning the distribution and equilibrium of population. Geography Review, 37, 461-485.

Suárez-Nuñez, C., y Gonzalez-Feliu, J. (2018). Freight trip generation modeling and data collection processes in Latin American cities: Modeling framework for Quito and generalization issues. In 2018 MIT SCALE Latin America Conference.

Taniguchi, E., y Thompson, R. G. (Eds.). (2015). City logistics: Mapping the future. CRC Press.

Thomas, I., Hermia, J. P., Vanelslander, T., y Verhetsel, A. (2003). Accessibility to freight transport networks in Belgium: a geographical approach. Tijdschrift voor economische en sociale geografie, 94(4), 424-438.

Tokman, V. E. (1978). Las relaciones entre los sectores formal e informal. Revista de la CEPAL, 1978(1), 103-142.

Toth, P., y Vigo, D. (Eds.). (2014). Vehicle routing: problems, methods, and applications. Society for Industrial and Applied Mathematics.

Troch, F., Vanelslander, T., Sys, C., Laroche, F., Merchan, A., Mostert, M., ... y Limbourg, S. (2017). A road map for explorative scenario creation on Belgian rail freight transport development. Competition and Regulation in Network Industries, 18(1-2), 3-21.

Turban, E., King, D., Sharda, R., y Delen, D. (2013). Business intelligence: a managerial perspective on analytics. Prentice Hall, New York.

Uchida, H., y Nelson, A. (2009). Agglomeration index: towards a new measure of urban concentration. Background paper for the WDR 2009.

Van Wee, B. (2016). Accessible accessibility research challenges. Journal of transport geography, 51, 9-16.

Vieira, J. G., Carvalho, C. D., y Yoshizaki, H.Y. (2016). Atributos da distribuição de carga e indicadores de desempenho logístico: pesquisa com empresas que atuam na região metropolitana de São Paulo. Transportes, 24(4), 10-20.

Vignoli, J. R. (2002). Distribución territorial de la población de América Latina y el Caribe: tendencias, interpretaciones y desafíos para las políticas públicas (Vol. 32). United Nations Publications.

Ville, S., Gonzalez-Feliu, J., y Dablanc, L. (2013). The limits of public policy intervention in urban logistics: Lessons from Vicenza (Italy). European Planning Studies, 21(10), 1528-1541.

Wang, Z., Goodchild, A. V., y McCormack, E. (2016). Freeway truck travel time prediction for freight planning using truck probe GPS data. European Journal of Transport and Infrastructure Research, 16(1), 76-94.

Wang, Z., Goodchild, A., y McCormack, E. (2017). A methodology for forecasting freeway travel time reliability using GPS data. Transportation Research Procedia, 25, 842-852.

Watson, H. J., y Wixom, B. H. (2007). The current state of business intelligence. Computer, 40(9).

Wisetjindawat, W., y Sano, K. (2003). A behavioral modeling in micro-simulation for urban freight transportation. Journal of the Eastern Asia Society for Transportation Studies, 5, 2193-2208. 
Yachiyo Engineering Co. LTD, y Pacific Consultants International (2005). The master plan for Lima and Callao metropolitan area. Urban transportation in the Republic of Peru (Phase 1). FINAL REPORT, volume I. Report for the Japan International Cooperation Agency (JICA), Transport Council of Lima And Callao and Ministry of Transportations and Communications of The Republic of Peru.

Yang, C. C., Marlow, P. B., y Lu, C. S. (2009). Assessing resources, logistics service capabilities, innovation capabilities and the performance of container shipping services in Taiwan. International Journal of Production Economics, 122(1), 4-20.

Yogev, N., Fink, L., y Even, A. (2012). How Business Intelligence Creates Value. In ECIS Proceedings.

Zevallos Vallejos, E. G. (2003). Micro, pequeñas y medianas empresas en América Latina. Revista de la CEPAL, 79, 53-70.

Zhao, H. (2010). On Regional Logistics Demand Index System Construction. Logistics Sci-Tech, 2010(2). 